\title{
The public-private sector pay debate in Europe
}

Torsten Müller and Thorsten Schulten

Working Paper 2015.08 


\section{The public-private sector pay debate in Europe}

Torsten Müller and Thorsten Schulten

Working Paper 2015.08

european trade union institute 
Torsten Müller is a senior researcher at the European Trade Union Institute (ETUI) in Brussels. Contact: tmueller@etui.org

Thorsten Schulten is a senior researcher at the Wirtschafts- und Sozialwissenschaftliches Institut (WSI) within the Hans Böckler Foundation in Düsseldorf, Germany.

Contact: Thorsten-Schulten@boeckler.de

Brussels, 2015

๑Publisher: ETUI aisbl, Brussels

All rights reserved

Print: ETUI Printshop, Brussels

D/2015/10.574/47

ISBN: $1994-4446$ (print version)

ISBN: 1994-4454 (electronic version)

The ETUI is financially supported by the European Union. The European Union is not responsible for any use made of the information contained in this publication. 


\section{Contents}

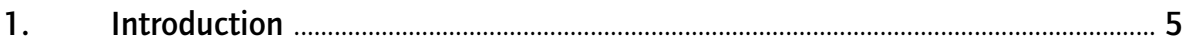

2. Public and private sector wage levels - is there an "unjustified"

pay gap?

2.1 Methodological problems with the analysis of private and public sector wages

2.2 Empirical findings on the public-private sector pay gap .......................................... 8

3. Impact of public sector wages on competitiveness - is there a wage leadership of the public sector?

3.1 Different mechanism on how public sector wages might influence

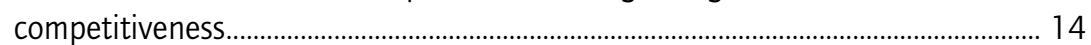

3.2 Is there a public sector wage leadership? ............................................................ 16

4. Public and private sector wages in Europe - an empirical investigation of recent developments ........................................................................................... 19

4.1 Average public and private sector wage levels in Europe in 2012 …................... 19

4.2 Development of public and private sector wage levels between 2001 and 2013 .............................................................................................................. 21

5. Conclusions ................................................................................................. 25

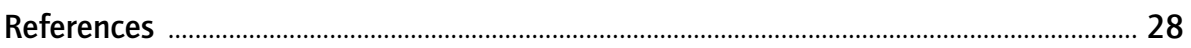

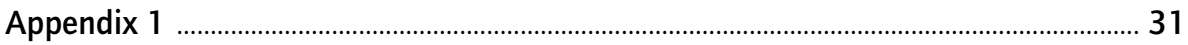

Appendix 2 .......................................................................................................................... 33 



\section{Introduction}

Public sector pay cuts and freezes have been frequently imposed by national policy makers to cope with the current economic crisis. This in particular applies to those countries that were in need of international financial assistance, because the financial bail-out packages were subject to the implementation of certain reforms, which always included public pay cuts and freezes (Schulten and Müller 2015). Two main arguments and justifications have been used by European and national policymakers for cuts and freezes of public sector pay in the context of the crisis: The first one refers to the need to reduce public spending in order to stabilize government finances and to reassure bond markets. The second main argument refers to the need to reduce the public sector wage bill in order to improve private sector competitiveness.

The first line of argument follows the logic of expansionary austerity (Giavazzi and Pagano 1990; Alesina and Ardagna 2010), which implies that under certain circumstances, major reductions in government spending might actually expand private consumption, and thereby lead to overall economic growth. The underlying rationale of this logic is what Paul Krugman (2013) called "the belief in the confidence fairy"; i.e. the fact that credible attempts at fiscal consolidation by seriously cutting public spending will increase the market actors' confidence and - based on low interest rates - will induce them to higher investment and consumption spending right away, thereby creating growth and employment. Since public sector wages on average account for more than $20 \%$ of total public spending in the EU (Hernández de Cos and Moral Benito 2013: 15), cuts and freezes in public sector wages play a major role in this approach.

This is not the place to review this line of argument in more detail. Ample criticism was raised by Krugman, who showed that the effects of the "confidence fairy" were not strong enough to offset the direct negative economic consequences of cuts in public spending in terms of depressed demand (Krugman 2013, 2014). Further support for this critical view has been provided by recent working papers published by the IMF, which found that the method used by previous studies to identify fiscal consolidation tended to overestimate the expansionary effect while at the same time downplaying the contractionary effects (Guajardo et al. 2011, Blanchard and Leigh 2013).

The main focus of this paper is on the critical review of the second main argument put forward to justify cuts in public sector wages: the assumed positive effect of cuts in public sector wages on private sector cost competitiveness. This justification is based on the assertion that "excessive" 
wage developments in the (sheltered) public sector drive up wages in the (exposed) private sector, undermining the (cost) competitiveness of the exportoriented sector in these countries. This assertion is politically highly influential and finds its clearest institutional expression in the Euro Plus Pact from 2011 which explicitly calls on EU member states to "ensure that wages settlements in the public sector support the competitiveness efforts in the private sector" (European Council 2011: 16). Similar demands and policy recommendations were also part of the memoranda of understanding between the Troika and Greece, Ireland, Portugal and more recently Cyprus.

The key objective of this paper is to provide a critical assessment of the empirical evidence and the underlying assumptions on which these policy recommendations are based. In section two, we will first review the findings of current cross-national comparative studies on differentials in public and private sector pay levels and assess the widespread claim that there is an "unjustified" public sector wage premium - i.e. a wage premium which is not justified by individual characteristics such as higher educational attainment, skills levels and age/seniority of public sector workers. In section three we will examine recent studies on the relation between public sector wages and competitiveness and discuss the widespread assumption of public sector wage leadership. In section four we will present our own empirical investigation on pay levels and developments in the public and private sector based on an analysis of data from the Eurostat Labour Cost Statistics. Finally, the concluding section will summarize the key results and what this means for the role of public sector wages in the broader context of the current crisis management. 


\section{Public and private sector wage levels - is there an "unjustified" pay gap?}

\subsection{Methodological problems with the analysis of private and public sector wages}

There is a widespread view that throughout Europe, average wages in the public sector tend to be higher than in the private sector. The European Commission has recently published two major comparative studies which try to provide empirical evidence for a significant public-private sector pay gap (De Castro et al. 2013, European Commission 2014a). Comparing public and private sector wages, however, always raises the fundamental methodical problem that official data such as that provided by Eurostat or other national and international data providers do not distinguish between the two sectors.

The study by the European Commission (2014a), for example, refers only to government wages and therewith excludes major parts of the public sector such as education, health and social services. As wages in public administration are usually much higher than in other public services (Christofides and Michael 2013), a narrow focus on government wages systematically overestimates wage levels in the public sector. The study by De Castro et al. (2013) tries to avoid this problem by using data of the European Structure of Earnings Survey (SES), which contains information on whether the employees are working in a company under private or public ownership. With the focus on ownership, however, the European comparison of public-private sector pay gaps is not based on a common definition but is heavily influenced by the highly variable national composition of the public sector.

Apart from the problem of using an adequate definition of the "public" and "private" sector, comparisons between public and private sector wage levels also have to take into account various composition effects, since employees in the public and the private sector show strong differences regarding their individual and occupational characteristics such as skills, gender, age, experience and education. The public sector, for example, has in many European countries seen an increasing outsourcing of low-skilled and low-paid activities to the private sector, which statistically increases average wages in the public sector without a change of the wage situation of the remaining employees (Vaughan-Whitehead 2013: 18). 
There is a large body of literature dealing with differences in public and private sector wage levels on a single-country basis ${ }^{1}$. Due to the problems in obtaining homogenous cross-national comparative data, it is only fairly recently that a range of studies have addressed this issue from a comparative perspective. The main focus of our review of the empirical evidence will be on the results of these more recent comparative studies. The objective of many of these studies published by the European Central Bank and the European Commission's DG ECFIN has been to investigate whether there is an "unjustified" wage premium in the public sector - i.e. one that cannot be explained by differences in individual or occupational characteristics. The underlying assumption of these studies is that an "unjustified" public sector wage premium spurred by "imprudent and sub-optimal wage-setting in the government sector may have been at the source not only of mounting public finance problems and fiscal pro-cyclicality in good times, but could have contributed to sow the seeds of competitiveness losses spreading to the tradable sector and feeding growing imbalances" (European Commission 2014a: 2). Thus, what these studies are actually trying to show is that excessive public sector wage developments in the southern European countries is not only one crucial factor contributing to their public debt problems, but that it is also is a major cause of their competitiveness problems. We will engage with this argument in the next chapter of this paper. Before doing this, we will summarize what the comparative studies have to say about the impact of individual and occupational characteristics on the public-private sector pay gap.

\subsection{Empirical findings on the public-private sector pay gap}

The overall picture drawn by recent comparative studies on public-private sector pay differentials is rather diverse and often inconsistent. According to de Castro et al. (2013: 18), there is an "unexplained" average public sector pay premium for the whole EU of 3.6\%. Compared to the overall difference of 10.5\% found by de Castro et al. (2013: 16) when not taking into account individual characteristics, the unexplained component is fairly small. However, this average figure obviously masks large national differences, ranging from a positive pay premium of more than $20 \%$ in Ireland, Cyprus and Luxembourg to a negative pay premium of more than $15 \%$ in Estonia and Hungary (de Castro et al. 2013: 17). Another interesting aspect is the fact that for some countries (i.e. Bulgaria, Czech Republic, Latvia, Estonia, France, Romania and Slovakia) a positive overall pay difference turns into a negative public sector pay gap when controlling for individual and occupational characteristics.

A further factor to be taken into account when looking at the public-private sector pay gap, are the diverse results of different cross-national comparative

1. For a comprehensive overview of these single country studies see Giordano et al. 2011: 11-14 and Grimshaw et al. 2012: 27-31. 
studies, because there are significant differences as regards the size of the pay gap. For Belgium, Spain, Italy, Portugal and Slovenia, the pay gap established by de Castro et al. (2013) is considerably lower than that found by Giordano et al. (2011). For France the difference is even more striking. Whereas Giordano et al. (2011) found a public sector pay premium, the findings by de Castro et al. (2013) and the European Commission (2014a) suggest the existence of a public sector pay penalty for France.

The variation in research findings can be explained by a whole range of factors. One of the most important factors obviously is the data source used. The Eurostat Structure of Earnings Survey (SES) used by de Castro et al. (2013) and the European Commission (2014a) for instance does not include wage data from workers belonging to NACE category $\mathrm{O}$ (public administration and defence; compulsory social security) or from so-called "micro-companies" with less than 10 employees. The exclusion of such a substantial part of the workforce may influence the research findings on the pay gap. In particular, since in 2011, almost $30 \%$ of employees in the EU-28 worked in such microcompanies (Eurostat 2013: 2).

Another factor related to the choice of the data source is the difference in the definition of the public sector. The SES definition for instance refers to all employees that report to be employed in entities owned by the government i.e. with a public property share higher than 50\% (European Commission 2014a: 15). This definition is problematic because, as already mentioned, the results are heavily influenced by the differences in the composition of the public sector. By contrast, the EU-Statistics on Income and Living Conditions (EU-SILC), which Giordano et al. (2011) used for their analysis, is based on NACE categories. According to the EU-SILC, the public sector includes workers who are employed in one of the following sectors: Public administration and defence; compulsory social security (NACE category O), education (NACE category P) and human health and social work activities (NACE category Q).

Another factor that influences the measurement of the pay gap is the type of wage considered. Giordano et al. (2011: 21) found that using monthly gross earnings rather than hourly gross earnings decreases the pay differentials by almost 3 percentage points - which in turn is almost as much as the "unexplained" average public sector pay premium established by de Castro et al. (2013).

The time period covered obviously has an impact on the results as well. The latest SES dataset used in the studies by de Castro et al. (2013) and the European Commission (2014a) dates back to 2010. The study by Giordano et al. (2011) only covers the period 2004-2007. This not only leads to different results but it also means that there is a considerable time lag, such that the findings do not take into account the far-reaching cuts and freezes in public sector pay which took place in the light of the crisis in particular in the southern European countries (for an overview see Grimshaw et al. 2012, ILO 2013, Schulten and Müller 2015). 
With all these caveats in mind, it is possible to distill the following key findings of more recent cross-national comparative research that controls for individual and occupational characteristics. According to the studies issued by the European Commission, there seems to be a public sector pay premium in many western European countries plus Slovenia, and a public sector pay penalty in the central and eastern European countries plus France, Denmark and Finland. For Lithuania, Malta, the Netherlands, Romania and the UK, no significant differences were found in the most recent studies by de Castro et al. (2013) and the European Commission (2014a).

A similar diversity of results can be found with respect to the analysis of the gender-specific public-private sector pay gap - both across the various EU countries as well as across different studies for the same country. Most older studies yielded a clear public sector pay premium for female workers (Giordano et al. 2011; Holm-Hadulla et al. 2010; Lucifora and Meurs 2004; Ponthieux and Meurs 2005). However, more recent studies found no "clear-cut" and "broad-based" evidence of such a wage premium (European Commission 2014a: 18; De Castro et al. 2013: 28). According to the studies by de Castro (2013) and European Commission (2014a), female public sector workers enjoy higher earnings only in "old" EU member states such as Germany, Spain, Ireland, the Netherlands, Belgium, Italy and Portugal.

The diversity of results is illustrated in Table 1 which summarizes the findings of some selected cross-national comparative studies with respect to the genderspecific public-private sector pay gap in France, Germany and the UK - three countries that were included in most comparative studies. Table 1 illustrates that the results are particularly diverse for France, ranging from a small public sector pay penalty for female workers (De Castro et al. 2013; European Commission 2014a) to a fairly significant public sector pay premium for female workers in the studies by Grimshaw et al. (2012) and Ponthieux and Meurs (2005). Once again the differences can be explained by a range of methodical aspects such as the use of different data sets and econometric techniques, the selection of different time periods and of course different definitions of public (and private) sectors.

The results for other individual characteristics such as age and educational attainment are similarly diverse which makes it difficult to draw general conclusions. Concerning the impact of educational attainment, most of the studies confirm the findings of previous studies that there exists a public sector wage premium for workers with lower levels of education and a pay penalty for workers with higher education. However, as the studies by de Castro et al. (2013) and the European Commission (2014a) show, there are also counter examples of countries such as Austria, Belgium, Cyprus, Ireland, Italy, Luxembourg, Portugal and Spain, where there exists a pay premium for high education public sector workers. Moreover, on average the public sector pay premium seems to be higher for older workers - but when also controlling for gender, the public sector premium seems to be higher in particular for young and older female workers (de Castro 2013: 28). 
Table 1 Research results on public-private pay gap from selected studies

\begin{tabular}{|c|c|c|c|c|}
\hline Authors & Data source & Countries & Workforce group & Public-private wage gap \\
\hline $\begin{array}{l}\text { De Castro et al. } \\
(2013)\end{array}$ & $\begin{array}{l}\text { SES Data (Eurostat), average hourly } \\
\text { earnings for } 2006 \text { and } 2010\end{array}$ & $\begin{array}{l}\text { France } \\
\text { Germany } \\
\text { UK }\end{array}$ & $\begin{array}{l}\text { All, Male, Female } \\
\text { All, Male, Female } \\
\text { All, Male, Female }\end{array}$ & $\begin{array}{l}0.96,1.00,0.95 \\
1.10,1.08,1.13 \\
\text { No significant wage gaps } \\
\text { (all figures 2010, adjusted) }\end{array}$ \\
\hline $\begin{array}{l}\text { European } \\
\text { Commission (2014) }\end{array}$ & $\begin{array}{l}\text { SES Data (Eurostat), hourly gross } \\
\text { earnings for } 2010\end{array}$ & $\begin{array}{l}\text { France } \\
\text { Germany } \\
\text { UK }\end{array}$ & $\begin{array}{l}\text { All, Male, Female } \\
\text { All, Male, Female } \\
\text { All, Male, Female }\end{array}$ & $\begin{array}{l}0.96,1.00,0.95 \\
1.10,1.08,1.13 \\
0.99,1.00,0.98 \\
\text { (adjusted) }\end{array}$ \\
\hline $\begin{array}{l}\text { Giordano et al. } \\
\text { (2011) }\end{array}$ & EU-SILC, gross hourly pay & $\begin{array}{l}\text { Germany } \\
\text { France }\end{array}$ & $\begin{array}{l}\text { All, Male, Female } \\
\text { All, Male, Female }\end{array}$ & $\begin{array}{l}1.11,1.02,1.19 \\
1.05,1.04,1.07 \\
\text { (adjusted) }\end{array}$ \\
\hline $\begin{array}{l}\text { Grimshaw et al. } \\
\text { (2012) }\end{array}$ & National data, gross average, 2010 & $\begin{array}{l}\text { France } \\
\text { Germany } \\
\text { UK }\end{array}$ & $\begin{array}{l}\text { Male FT, Female FT } \\
\text { All, Male, Female } \\
\text { All, Male, Female }\end{array}$ & $\begin{array}{l}1.10,1.13 \\
0.93,0.95,1.04 \\
1.15,1.17,1.29\end{array}$ \\
\hline $\begin{array}{l}\text { Holm-Hadulla et al. } \\
\text { (2010) }\end{array}$ & OECD data & $\begin{array}{l}\text { Germany } \\
\text { France }\end{array}$ & $\begin{array}{l}\text { All } \\
\text { All }\end{array}$ & $\begin{array}{l}1.22 \\
1.04\end{array}$ \\
\hline $\begin{array}{l}\text { Lucifora and Meurs } \\
\text { (2004) }\end{array}$ & National data - log hourly wage & $\begin{array}{l}\text { France } \\
\text { UK }\end{array}$ & $\begin{array}{l}\text { Male, Female } \\
\text { Male, Female }\end{array}$ & $\begin{array}{l}1.05,1.10 \\
1.07,1.13\end{array}$ \\
\hline $\begin{array}{l}\text { Ponthieux and } \\
\text { Meurs (2005) }\end{array}$ & ECHP, gross monthly pay, 2000 & $\begin{array}{l}\text { France } \\
\text { Germany } \\
\text { UK }\end{array}$ & $\begin{array}{l}\text { Male, Female } \\
\text { Male, Female } \\
\text { Male, Female }\end{array}$ & $\begin{array}{l}1.13,1.26 \\
1.12,1.21 \\
1.02,1.18\end{array}$ \\
\hline
\end{tabular}

Source: Authors' compilation on the basis of Grimshaw et al. 2012: 23

All in all, de Castro et al. conclude that the overall public sector premium - where it exists - can "mainly be explained by the sizeable gaps observed at lower job positions" (2013: 28). Christofides and Michael came to the same conclusion stating that "less educated workers tend to have larger unexplained gaps" (2013: 23). The latter is consistent with the findings of industrial relations research which found that the often more centralized wage formation systems in the public sector promote lower wage dispersion than in the private sector (Schulten and Brandt 2012).

Interestingly, of the cited studies, only the one by Giordano et al. (2011) and the European Commission (2014a) actually investigate the role of institutional factors such as trade union density and bargaining power, private sector employment protection legislation (EPL), and the size of general government as an employer. The results show only limited impact of institutional factors - at least when judged on the basis of statistical correlations. According to both studies, the trade unions' bargaining power measured in terms of the unions' right to strike and trade union density is not significantly positively correlated with a public sector wage premium. This finding goes hand in hand with the finding concerning the size of the public sector and the importance of general government as an employer. This factor seems to be negatively related to the public sector pay premium. According to the European Commission (2014a: 20), this can be taken as a sign 
that a larger government sector can use its monopsonistic bargaining power to push through lower wages in negotiations (or to set wages accordingly in countries where there is no tradition of collective bargaining in the public sector).

This brings us to the impact of wage-setting arrangements more generally. Here, the European Commission reports some evidence that the share of countries with a positive public sector wage premium is lower amongst those countries in which public sector wages are negotiated than amongst those countries in which public sector wages are traditionally set unilaterally by government decision (2014a: 20). In their study, the European Commission takes this as a partial confirmation of the hypothesis that public sector wage premia tend to be lower in countries where government wages are set through collective bargaining rather than through unilateral legislative decisions.

The only seemingly unambiguous result concerned the impact of the private sector employment protection legislation. The European Commission study found a statistically significant correlation between strong employment protection in the private sector and a public sector pay premium (2014a: 20). This can be explained by the fact that in the light of strong private sector EPL, wages in the public sector need to be high in order to attract workers to the public sector.

Another factor considered was the type of contract/employment. In this respect the study by the European Commission (2014a: 16) found some evidence suggesting a public sector premium for permanent and fixed-term contracts and apprentices. Breaking down the analysis to sub-sectors of the public sector, Giordano et al. (2011: 21) found that the public-private sector pay differentials are generally higher in the education and the public administration sectors rather than in the health sector. However, the authors also point out that this result should be taken with a grain of salt, because the larger differentials for the education sector, for instance, may partly be explained by the fact that teachers for instance may have underreported their hours worked by only referring to the number of hours they spend teaching (Giordano et al. 2011: 19). Since, however, hourly wages are calculated "by dividing the employees' gross monthly earnings by the hours they usually work each week" (Giordano et al. 2011: 16) reporting errors on the hours worked potentially distort the results.

From the summary of the key findings of recent cross-national comparative studies, it should have become clear that there is no straightforward answer to the question posed at the beginning - whether or not there is an "unjustified" public sector wage premium. Partly this is because of the strong inter-country variation of the findings, which - echoing Grimshaw et al. (2012: 22) - calls for a more detailed understanding and qualitative analysis of country patterns and wage setting mechanisms. Partly this is also because of the intra-country variation of the findings; i.e. the differences in the findings for one country depending on the data set and the statistical method used for the analysis. Some methodical problems concerning the sample construction, the definition 
of public and private sectors and the choice of the time period covered have already been mentioned. Another more general shortcoming of the data mentioned by Giordano et al. (2011) is the fact that it is almost impossible to capture the whole pay package when comparing developments in the public and private sector because the data is simply not available. This concerns fringe benefits which are typically higher in the private sector, pension rights which are generally higher in the public sector, but also non-monetary factors which might influence the employees' preference to work either in the public or the private sector. 


\section{Impact of public sector wages on competitiveness - is there a wage leadership of the public sector?}

The debate about the public-private sector pay gap feeds directly into the broader political debate about the relationship between the development of public-private sector wage differentials and a country's competitiveness (and linked to this, the development of macro-economic imbalances). At the heart of much of this debate is the assumption that spillovers from "excessive" wage developments in the (sheltered) public sector contribute to competitive losses of the (exposed) private sector, and in doing so contribute to the growing external imbalances within the EMU. According to the currently dominant interpretation of the crisis, one of the key challenges in particular for small and open economies is that wages are set in the non-tradable (i.e. public) sector in such a way that the cost competitiveness of the tradable (i.e. private) sector is not undermined (Lamo et al. 2012: 230). Against this background, the objective of the remainder of this section is to assess the validity of this assumption by reviewing the empirical evidence provided by current research.

\subsection{Different mechanism on how public sector wages might influence competitiveness}

The relationship between public-private sector wage differentials and competitiveness is closely linked with the research into the "unjustified" public sector wage premium outlined above. According to the literature, there are essentially three different mechanisms how changes in public sector wages may affect private sector wages and competitiveness. The first mechanism is seen to act more directly through established practices of public sector wage leadership. Following this logic, public sector wage growth may have a signaling effect exerting pressure on private sector negotiators to follow developments in the public sector (Afonso and Gomes 2008: 27). The second mechanism is related to the labour market, because "unjustified" public sector wage premia may lead to a persistently sub-optimal supply of skilled labour to the private sector which pushes up the equilibrium wage and in doing so negatively affects national competitiveness and growth potentials (European Commission 2014a: 3). The third channel is related to a price effect, because "excessive" wage developments in the public sector drive up aggregate national inflation (if not compensated by private sector wage moderation) with negative consequences for relative price competitiveness and export performance thus leading to current account deficits (Johnston et al. 2013: 17). 
The statistical correlation between the development of public-private sector pay differentials and the development of the current account balance has been investigated by the European Commission (2014a) using data from the OECD and the DG ECFIN Ameco database for the period 1999-2007. The Commission study found that "deteriorations in current account balances were somewhat more marked in countries where government wages were growing at faster pace than manufacturing wages" (2014a: 29). However, a closer look at the data reveals that this argument only stands up for Ireland and Italy. There are several examples which prove the opposite. Poland and Hungary, for instance which according to the Commission study are the two countries with the highest annual average growth in public-private pay differentials, show no negative developments in the annual average change in their current account. Other counter examples are France and Finland. According to the Commission study, these two countries report the same negative annual average changes in their current account as Ireland and Italy, but the annual average change of the public-private wage differential in France and Finland is actually slightly negative. The Commission study, therefore, provides no clear-cut empirical evidence for a causal relationship between the development of wage differentials and current account developments.

An institutionalist variant of this argument has been put forward by Hancké (2013) and Johnston et al. (2013), who found a positive correlation between small public-private sector pay gaps and a positive export performance and current account surpluses as two indicators for a country's competitiveness. According to their argument, the different export performances and current account developments can be explained by the countries' different institutional capacities to prevent "excessive" public sector wages from undermining private sector competitiveness through different mechanisms of coordinating wage developments in the two sectors. Thus, for Hancké (2013) and Johnston et al. (2013), the national differences in wage-setting arrangements are the key factor explaining national differences in competitiveness.

They state that the most successful countries are therefore the ones in which the wage-setting institutions link wage growth in the sheltered (public) sector to wage developments in the private sector exposed to international trade and in doing so ensure overall wage restraint. According to Johnston et al. (2013: 21), this can best be achieved in systems with exposed/private sector wage leadership and in systems in which the state plays an important role in wage-setting. Johnston et al. (2013: 23) identify three different variants which fulfill these criteria: (1) systems of pattern bargaining with export sector wage leadership like in Austria, Germany and Sweden; (2) state-coordinated systems like in Belgium and France; and (3) systems of incomes policy and wage pacts with high governability like in Finland at different points in time and in the Netherlands in the early 2000 .

By contrast, the key problem of countries like Spain, Italy, Portugal and Ireland was that their peak-level bargaining systems with low governability lacked the capacity to constrain sheltered sector wage growth. This in turn led to an increase of aggregate national inflation and real exchange rate which eventually 
resulted in a deterioration of price/export competitiveness. Thus, following this argument, even though there is not necessarily a direct link between wage developments in the public and private sector, excessive public sector wages can still influence competitiveness developments in the private sector through its impact on national inflation.

Based on this analysis, Johnston et al. see the need for a "symmetric adjustment" (2013: 40) which implies a policy of wage moderation in the southern European countries and simultaneous wage increases in the northern European surplus countries in order to boost demand. This process of "symmetric adjustment" needs to be underpinned by structural adjustments of wage-setting systems in the southern European countries in order improve their capacity to coordinate wage developments in the public and private sectors with the exposed private sector in the driving seat. The argument by Johnston et al. (2013) rests on two assumptions. The first assumption is that public sector wages in particular in the southern European countries outpaced private sector wages. The second assumption is that public sector wages exert a strong influence on private sector wages by whichever channel. In the following this paper will review the empirical evidence provided by the literature on wage leadership which explicitly analyses the interaction between public and private sector wages and the factors which determine either public or private sector wage leadership.

\subsection{Is there a public sector wage leadership?}

At a more general level, the analysis of an OECD dataset for 18 countries by Lamo et al (2012a) shows that overall private sector wages exert a stronger influence on public sector wages rather than vice versa. This is in line with the findings of other studies such as the one by Pérez and Sánchez (2010) who also found a strong signaling effect of private sector wages and the one by Zeilstra and Elbourne (2014) who in their single-country study of the Netherlands found no indication of a public sector wage leadership. However, as table 2 illustrates, the study by Lamo et al. (2012a) also shows that the direction of the influence differs depending on whether one looks at developments in the short-run or in the long-run. Two findings deserve to be highlighted: firstly, in all the countries the long-run public sector wage leadership turns into a private sector wage leadership when looking at the relationship between the two sectors in the short-run (for Ireland and the Netherlands no data was available for the short-run relationship). The second surprising result is that in particular in the southern European countries Greece and Portugal in both the long run and in the short run, private sector wages influence public sector wages rather than the other way round. This runs counter to the commonly made argument that in the crisis countries in particular excessive wages in the public sector drive up wages in the private sector. The explanation given for this finding is that stricter EPL in these countries gives private sector unions a stronger bargaining position independent of developments in the public sector, which in turn might weaken the influence of public sector wages (Lamo et al. 2012a: 241). As a matter of fact, a short-run public sector wage leadership was only found for Spain and (to a lesser extent) in the UK. 
Table 2 Public-private sector wage leadership (1970-2006)

\begin{tabular}{|c|c|c|}
\hline & Long run & Short run \\
\hline Public sector wage leadership & $\begin{array}{l}\text { Belgium, Denmark, Finland, France, } \\
\text { Germany, Ireland, Norway, } \\
\text { Netherlands }\end{array}$ & Spain, UK (to a lesser extent) \\
\hline Private sector wage leadership & $\begin{array}{l}\text { Austria, Canada, Greece, Italy, } \\
\text { Portugal, Sweden, Spain, UK, US }\end{array}$ & $\begin{array}{l}\text { Austria, Belgium, Canada, Denmark, } \\
\text { Finland, France, Germany, Greece, } \\
\text { Italy Netherlands, Portugal, US }\end{array}$ \\
\hline
\end{tabular}

Source: Lamo et al. $2012 a$

However, another study investigating short-run relations between wage growth in the government and in the private sector found that private sector wages are much more responsive to government wage increases than the other way round (European Commission 2014a,). According to the Commission study, a 1\% increase of government wages raises private sector wages by almost $1 \%$ on average. The strongest short-run private sector responses to government wage increases were found in Italy, Portugal and Spain (European Commission 2014a: 27). In another paper, however, the European Commission came to the rather different result that "manufacturing wages usually have a greater impact on government wages" which "is arguably because private sector wage leadership is more common than public sector wage leadership" (2014c: 34, our emphasis).

However, since the studies by the European Commission on wage leadership are merely based on statistical correlations and do not take into account country-specific institutional factors such as wage-setting systems and practices of wage leadership, the studies have little to say about the factors that actually account for this specific relationship. The number of studies that explicitly investigate the institutional determinants of the linkages between public and private sector wages is very limited. Among the few that exist is that by Lamo et al. (2012b) which, on the basis of a statistical analysis of an OECD dataset for 18 countries, explicitly investigates the institutional factors that determine public sector wage leadership. The authors found that neither EPL nor other institutional features such as the degree of bargaining coordination and trade union density play a significant role in determining public sector wage leadership. This is surprising because it contradicts Lamo et al.'s argument that strong EPL in the southern European countries weakens the influence of public sector wages on wage developments in the private sector (Lamo et al. 2012a: 241).

According to Lamo et al. (2012b: 5), public sector wage leadership is more likely when the government is involved in the bargaining process, in highly centralized bargaining arrangements, and in collective bargaining systems with a predominance of regional negotiations. By the same token, the following institutional factors reduce the probability of public sector wage leadership: stronger exposure of the private sector to international competition and the prevalence of company-level bargaining (Lamo et al. 2012b: 6). 
A more holistic approach was chosen by Brandl and Traxler (2008) and Traxler et al. (2008) in their analysis of pattern bargaining in Austria as one variant of wage leadership more generally by combining quantitative and qualitative methods. Whereas the statistical analyses merely focused on the outcome of the bargaining process and its correlation with a range of variables, the combination of quantitative and qualitative methods not only enables a closer look at the process as such but it also means that the analysis of the determining factors is actually based on the account and interpretations of the people directly involved in the negotiations. Thus, power relations and the actors' interests are also considered in the analysis. The downside of this more holistic approach is the trade-off between the depth and breadth of the analysis.

Against this background, Brandl and Traxler (2008) and Traxler et al. (2008) found that the key factor that underpins wage leadership of the metalworking sector in Austria is the powerful position of the metalworking union relative to the other sectors - and in particular to the public sector union, which at the time of writing actually had more members than the metalworking union. It is therefore the specific combination of the following factors on which the metalworking union's leading role is based: the large and powerful membership base, the macroeconomic weight of the metal industry in Austria, the formal constraints on public sector union's bargaining power including the right to strike and, finally, the "bargaining routines that reinforce expectations of pattern bargaining in the media and the public to the extent that even reluctant bargaining units feel compelled to follow" (Traxler et al. 2008: 54).

The findings for the single case of Austria illustrate the need for more contextualized and actor-based analyses in order to include into the analysis the dimension of power and the interests and perceptions of the actors involved. This is not to disregard the findings of statistical analyses. They provide important insights into empirical phenomena. However, in view of the inter-country and intra-country variation of the results depending on the data used and the statistical methods applied, there is an obvious need to complement quantitative analyses with more in-depth qualitative analyses. This would enable moving from mere description and educated guessing towards understanding and from discovering correlations towards actually establishing causal relationships. 


\section{Public and private sector wages in Europe - an empirical investigation of recent developments}

As the existing empirical studies have not yielded a clear picture either of the levels or of the different developments of public and private sector wages, in this section, we will present the results of our own empirical investigation. In the following we examine available comparative data from the Eurostat Labour Cost Survey (LCS) and the Eurostat Labour Cost Index (LCI) respectively which have not been utilized in other studies so far. Compared to other data sources, such as the SES or the EU-SILC data, using the Eurostat data on labour costs has two main advantages. First, since the labour cost data is broken down into three main categories (gross wages and salaries, employers' social security contributions and other labour costs), the data provides detailed information about wages and salaries on an hourly, monthly and annual basis. This distinction can be very important because - as will be shown later - it can make a substantial difference when comparing pay levels and developments in the public and private sector. Another advantage is the broader coverage supplied because the Eurostat data on labour costs is provided at an aggregate level which comes close to the definition of the private and the public sector. The "private sector" comprises all economic activities which according to the standard statistical classification of economic activities are covered under the NACE Codes B-N and are summarized by Eurostat under the term "business economy". The "public sector" includes all economic activities covered by NACE Codes O-S including public administration, defense, compulsory social security, education, health and social services, entertainment and recreation and other services $^{2}$. However, the presentation of the data at a highly aggregated level also comes at a cost because it is not possible to take into account and to control for individual characteristics such as gender, age, seniority, educational attainment and skills levels which, as other more recent comparative studies have shown, tend to reduce the public sector pay gap substantially.

\subsection{Average public and private sector wage levels in Europe in 2012}

The most recent available LCS data, on which our analysis of public and private sector wages in Europe is based, is from 2012 and covers 23 out of $28 \mathrm{EU}$ countries (Table 3). ${ }^{3}$ No data was available for Austria, Belgium, Greece, Malta

2. It should be mentioned that the Eurostat labour cost data does not include wage data for establishments with less than 10 employees.

3. All data is available online under $:$ http://ec.europa.eu/eurostat/data/database 
Table 3 Wages in the private and public sector, 2012

(per employee in full-time units, establishments with 10 employees or more)

\begin{tabular}{|c|c|c|c|c|c|c|c|c|c|}
\hline & \multicolumn{3}{|c|}{ Private sector in Euro } & \multicolumn{3}{|c|}{ Public sector in Euro } & \multicolumn{3}{|c|}{$\begin{array}{l}\text { Public sector wages in } \% \\
\text { of private sector wages }\end{array}$} \\
\hline & per year & per month & per hour & per year & per month & per hour & per year & per month & per hour \\
\hline Bulgaria & 5,057 & 421 & 2.90 & 4,858 & 405 & 2.93 & 96.1 & 96.2 & 101.0 \\
\hline Croatia & 13,969 & 1,164 & 7.91 & 15,200 & 1,267 & 8.79 & 108.8 & 108.8 & 111.1 \\
\hline Cyprus & 25,108 & 2,092 & 13.84 & 25,125 & 2,094 & 15.38 & 100.1 & 100.1 & 111.1 \\
\hline Czech Rep. & 13,007 & 1,084 & 7.42 & 12,447 & 1,037 & 7.16 & 95.7 & 95.7 & 96.5 \\
\hline Denmark & 58,021 & 4,835 & 35.98 & 49,883 & 4,157 & 33.31 & 86.0 & 86.0 & 92.6 \\
\hline Estonia & 11,777 & 981 & 6.54 & 10,322 & 860 & 5.97 & 87.6 & 87.7 & 91.3 \\
\hline Germany & 41,024 & 3,419 & 25.00 & 37,709 & 3,142 & 23.07 & 91.9 & 91.9 & 92.3 \\
\hline Finland & 41,244 & 3,437 & 25.13 & 36,228 & 3,019 & 23.63 & 87.8 & 87.8 & 94.0 \\
\hline France & 36,675 & 3,056 & 23.33 & 29,674 & 2,473 & 20.13 & 80.9 & 80.9 & 86.3 \\
\hline Hungary & 10,749 & 896 & 6.01 & 8,656 & 721 & 4.88 & 80.5 & 80.5 & 81.2 \\
\hline Ireland & 41,300 & 3,442 & 24.06 & 47,965 & 3,997 & 32.33 & 116.1 & 116.1 & 134.4 \\
\hline Italy & 31,826 & 2,652 & 19.35 & 31,833 & 2,653 & 22.71 & 100.0 & 100.0 & 117.4 \\
\hline Latvia & 8,927 & 744 & 4.94 & 8,050 & 671 & 4.57 & 90.2 & 90.2 & 92.5 \\
\hline Lithuania & 7,439 & 620 & 4.17 & 7,831 & 653 & 4.67 & 105.3 & 105.3 & 112.0 \\
\hline Luxembourg & 51,852 & 4,321 & 29.12 & 53,257 & 4,438 & 31.95 & 102.7 & 102.7 & 109.7 \\
\hline Netherlands & 43,750 & 3,646 & 24.64 & 42,041 & 3,503 & 26.87 & 96.1 & 96.1 & 109.1 \\
\hline Poland & 10,950 & 913 & 6.24 & 10,919 & 910 & 7.22 & 99.7 & 99.7 & 115.7 \\
\hline Portugal & 17,470 & 1,456 & 10.21 & 18,684 & 1,557 & 11.92 & 106.9 & 106.9 & 116.7 \\
\hline Romania & 6,102 & 508 & 3.29 & 5,424 & 452 & 2.96 & 88.9 & 89.0 & 90.0 \\
\hline Slovakia & 11,804 & 984 & 6.87 & 9,749 & 812 & 5.96 & 82.6 & 82.5 & 86.8 \\
\hline Slovenia & 22,144 & 1,845 & 12.94 & 23,692 & 1,974 & 14.18 & 107.0 & 107.0 & 109.6 \\
\hline Spain & 27,053 & 2,254 & 15.36 & 26,788 & 2,232 & 16.81 & 99.0 & 99.0 & 109.4 \\
\hline UK & 39,738 & 3,312 & 18.23 & 39,092 & 3,258 & 18.51 & 98.4 & 98.4 & 101.5 \\
\hline EU 28 & 32,275 & 2,690 & 18.33 & 30,107 & 2,509 & 18.13 & 93.3 & 93.3 & 98.9 \\
\hline
\end{tabular}

Private Sector: NACE Code B-N (Business economy)

Public Sector: NACE Code O-S (Public administration and defence; compulsory social security; education; human health and social work activities; arts, entertainment and recreation, other services)

Source: Eurostat, Labour Costs Survey 2012, calculations by the authors

or Sweden. It covers the year 2012 which in contrast to most other studies has the advantage that it includes already some of the cuts in public sector wages which were imposed after the outbreak of the crisis in 2008 and 2009 (Schulten and Müller 2015).

The Eurostat data shows that there are still enormous differences among the countries in both private and public sector wage levels, ranging from an hourly wage of more than 35 Euros in the Danish private sector to less than 3 Euros in Bulgaria. Comparing the two sectors, in most countries, hourly public sector wage levels were in a range between 15 percent below or above wage levels in the private sector. The two most extreme cases were Hungary with a public sector wage of only 81.2 per cent of the wage paid in the private sector, and Ireland where public sector wages were 34.4 percent above the wage level in the private sector. 
All in all, our findings confirm the results of previous studies of a highly diverse picture as regards the comparison of public and private sector wage levels across Europe. According to the Eurostat LCS data, there were 13 EU countries where average public sector wage levels were higher than in the private sector and $10 \mathrm{EU}$ countries where the opposite was the case. Both groups cover countries from almost all European regions - with the exception of those southern European countries for which data is available; i.e. Cyprus, Italy, Portugal and Spain. They all fall into the first group of countries with a higher average hourly wage level in the public sector. The private-public sector pay gap is usually diminished when not hourly wages but instead monthly or even annual wages are considered. This might reflect the fact that in the private sector employees often work more overtime and receive more extra payments and bonuses. On a monthly and annual basis, average wages in the public sector are higher than in the private sector only in a minority of eight out of 23 EU countries. Interestingly, the public sector premium in hourly wages in Cyprus, Italy and Spain disappears when monthly and annual average wages are used as the basis for comparison.

To sum up, recent figures on public and private sector wages levels in Europe do not confirm the widespread view that public sector wages are usually higher than wages in the private sector. On the contrary, the picture is much more differentiated; in around half of the EU Member States private sector wages levels are higher than in the public sector. To what extent the latter is mainly the result of recent public sector wage cuts has to be clarified by analysing more long-term wage trends in both sectors.

\subsection{Development of public and private sector wage levels between 2001 and 2013}

In the following, we analyse the development of private and public sector wages for the period 2001-2013 on the basis of the Eurostat labour costs index. ${ }^{4} \mathrm{We}$ first look at the period before the crisis between 2001 and 2009, as many studies on public-private sector wage gaps refer to this period. Figure 1 provides a comparison of wage growth in the private and the public sector in percentage points. Out of $22 \mathrm{EU}$ countries for which data is available, there are eight countries where public sector wages grew much faster than in the private sector with a difference of at least 10 percentage points. With the exception of Malta, all of these countries are from Eastern Europe where public sector wages have usually been lower than in the private sector, so that the more dynamic wage development in the public sector can be interpreted as a catching-up process.

Apart from that there were only two further countries where wages grew significantly faster in the public sector. These two countries were Ireland and Italy with a difference of 8 and 6 percentage points respectively, while in

4. A more detailed country by country analysis of the Eurostat labour cost data is provided in a data appendix to this study. 
Poland and the UK, wages in the public sector grew only slightly faster than in the private sector. Moreover, in the Benelux countries, public and private sector wages grew almost in line with each other. Finally, there were seven countries where public sector wage growth lagged behind that of the private sector. Among them were rather different countries such as Greece, Cyprus and Portugal, Germany and Finland as well as Slovenia and Latvia. Particularly striking here is the inclusion of Portugal and Cyprus in this group of countries because this contradicts the widespread claim that "excessive" public sector wage developments in the run-up to the crisis undermined the competitiveness of the private sector in these countries. In contrast to that, Greece seems to confirm the picture of a strong public sector wage leadership as public sector wages grew much faster in the period 2001 to 2008. The sharp cuts of public sector wages in 2009, however, have already more than offset the relative public sector premium of the 2000s (see the data on Greece in appendix 2).

Figure 1 Differences in public and private sector wage growth, 2001-2009 (in percentage points)

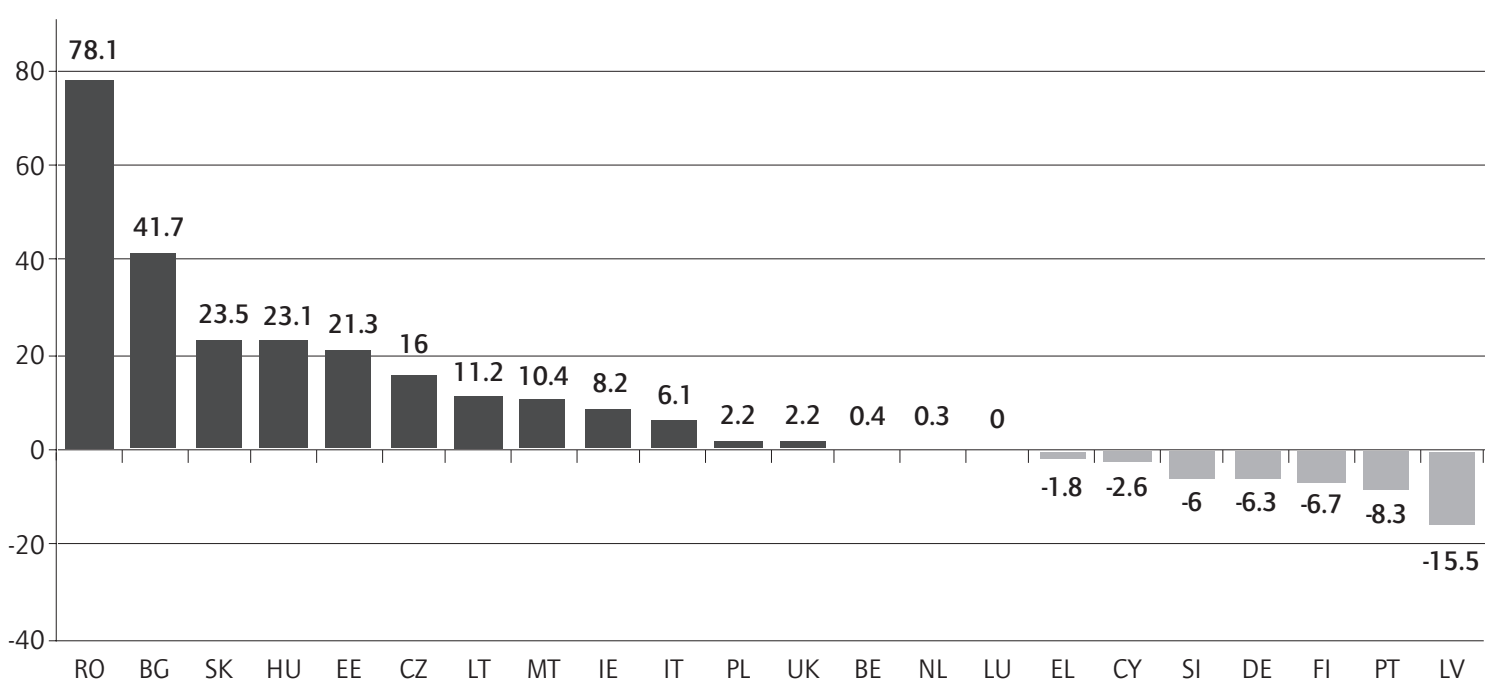

Private Sector: NACE Code B-N (Business economy)

Public Sector: NACE Code O-S (Public administration and defence; compulsory social security; education; human health and social work activities; arts, entertainment and recreation)

Source: Eurostat, calculations by the authors

Considering the whole period between 2001 and 2013, the picture changes dramatically as now public sector wages grew slower than wages in the private sector in 14 out of $22 \mathrm{EU}$ countries. In only eight countries, the opposite was the case (Figure 2). In many countries the relative strong public sector wage growth in the pre-crisis years has been more than offset by public sector wage cuts and freezes after the outbreak of the crisis.

The strong lag of public sector wage developments behind the private sector becomes clear when only the period 2010 to 2013 is considered. For this period, the Eurostat data covers all EU member states with the exception of Denmark (Figure 3). In recent years, there were only 4 out of 27 countries (Austria, 
Malta, Slovakia and the Netherlands) where public sector wages grew faster than wages in the private sector. In the great majority of 23 countries, the public-private sector wage gap changed in favour of the private sector.

Figure 2 Differences in public and private sector wage growth, 2001-2013 (in percentage points)

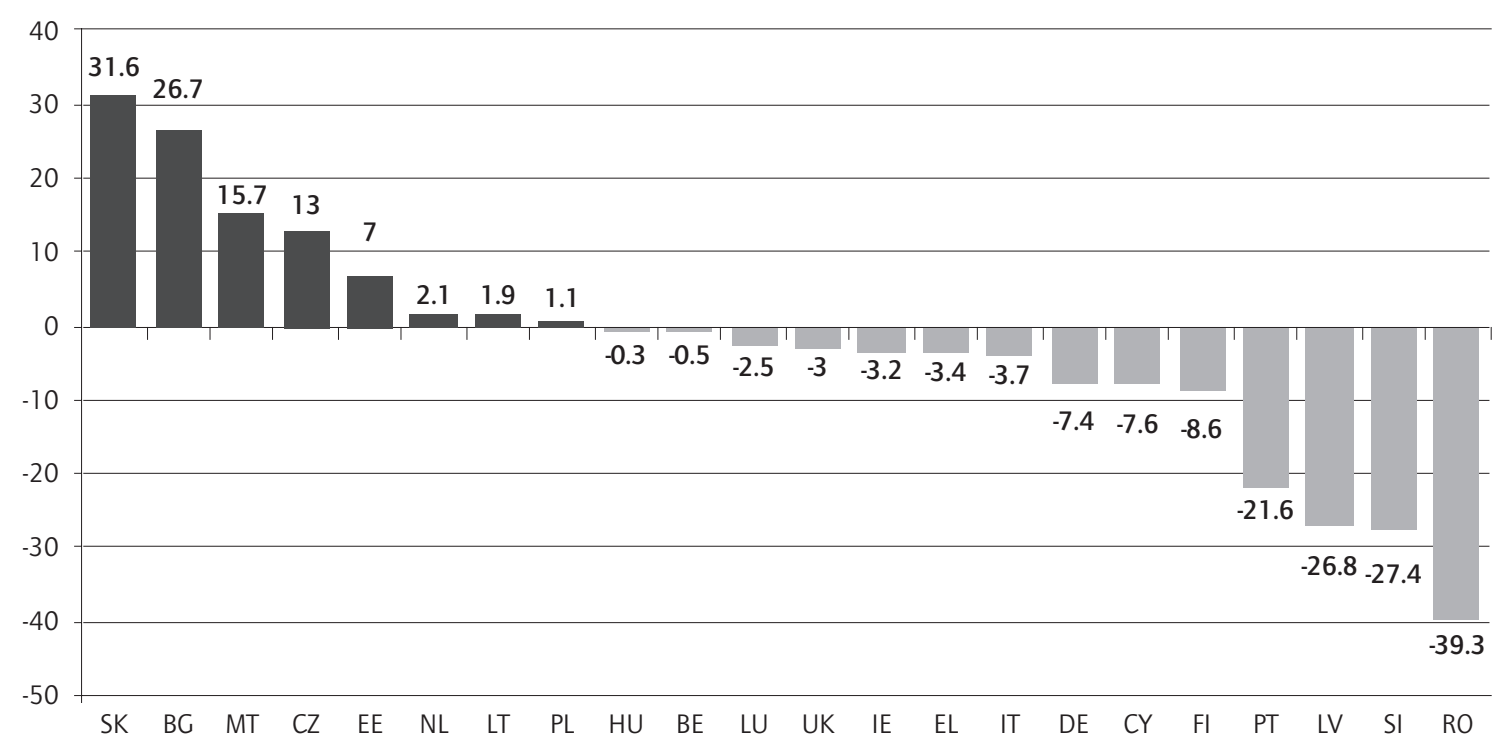

Private Sector: NACE Code B-N (Business economy)

Public Sector: NACE Code O-S (Public administration and defence; compulsory social security; education; human health and social work activities; arts, entertainment and recreation)

Source: Eurostat, calculations by the authors

Figure 3 Differences in public and private sector wage growth, 2010-2013 (in percentage points)

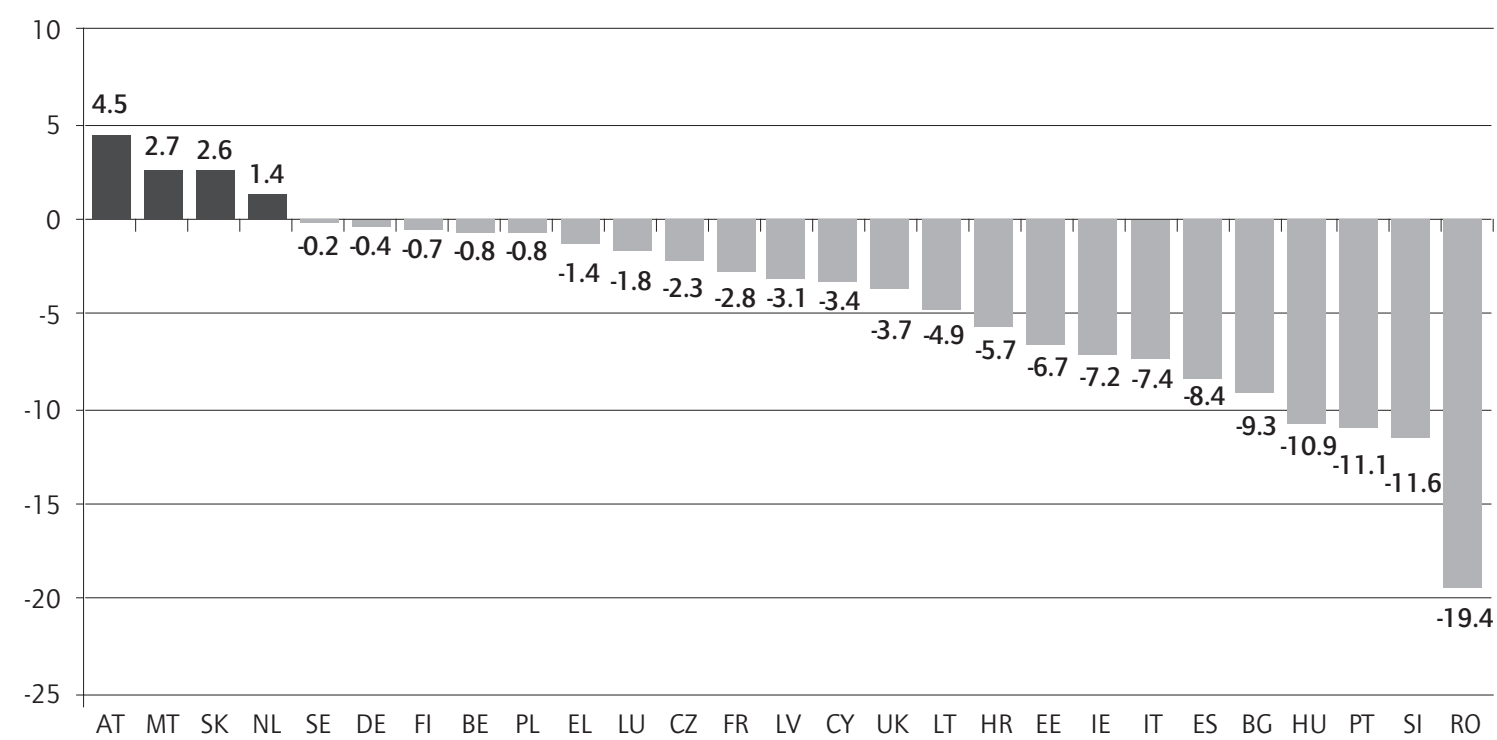

Private Sector: NACE Code B-N (Business economy)

Public Sector: NACE Code O-S (Public administration and defence; compulsory social security; education; human health and social work activities; arts, entertainment and recreation)

Source: Eurostat, calculations by the authors 
To sum up, the analysis of wage developments in the public and the private sector does not confirm the widespread thesis of a clear public sector wage leadership and the concomitant argument that 'excessive' public sector wage growth contributed to the competitiveness crisis in the southern part of the EU. Before the outbreak of the crisis in 2008/2009 the picture was rather mixed with some countries having a stronger public and others having a stronger private sector wage dynamic. In recent years, however, in most European countries there is strong pressure on the public sector whereby public sector wage growth has lagged (sometimes strongly) behind wage growth in the private sector so that in many cases the previous public sector pay premium turned into a pay penalty. 


\section{Conclusions}

The objective of this working paper was to critically review the empirical evidence and the basic assumptions on which European and national policymakers base their strategy of cutting and freezing public sector pay as one central element of the current crisis management. In the remainder of this concluding section, we will discuss each of the basic assumptions in the light of the empirical evidence provided in this paper before we then go on to reflect on what this means for the role of public sector wages in the broader context of the EU crisis management.

The first underlying assumption of the policy recommendations to cut and freeze public sector wages is that there actually exists an excessive public sector pay development in relation to pay developments in the private sector. The empirical data - both our own and the one of previous comparative studies does not support this assumption. What emerges is a highly diverse picture with respect to both wage levels and wage developments in the public and the private sector. Our own analysis of Eurostat data shows that, even in the precrisis period from 2001 to 2009, with very few exceptions, public sector wages only actually grew significantly faster than did private sector wages in those central and eastern European countries where public-sector wages were traditionally lower than in the private sector; clearly, the catching-up process goes some way towards explaining this phenomenon. In particular, the fact that during the pre-crisis period, public sector wages in some of the "crisis" countries such as Cyprus and Portugal grew slower than private sector wages, contradicts the assertion of "excessive" public sector wage developments as one major cause of competitiveness losses in the private sector of these countries.

The second basic assumption of the advocates of public sector wage cuts is that there is a link between public-private pay differentials and a country's competitiveness. Or put differently: if there were excessive public sector wage developments, they would drive up private sector wages and in doing so undermine the cost competitiveness of the private sector exposed to international competition. However, neither our own analysis of longer term wage developments in the two sectors nor Lamo et al's (2012b) statistical analysis provide any clear-cut evidence for public sector wage leadership and a strong influence of public sector wages on wages in the private sector. On the contrary - as is also confirmed by the European Commission (2014c) - there is often a mutual influence of private and public sector wage developments, and even a strong private sector leadership in some European countries. 
Even if - for the sake of the argument - we assume a significant impact of public-private sector wage differentials on a country's competitiveness, the argument is still flawed because it essentially rests on an excessively narrow conception of competitiveness as cost competitiveness. Such a narrow conception disregards the evidence of several studies that emphasize the importance of non-price competitiveness for economic growth. The studies by Felipe and Kumar (2011) and Storm and Naastepad (2014), for instance, show that unit labour costs only play a marginal role for export performance and the current account balance. According to calculations by Storm and Naastepad (2014: 8), unit labour costs make up only $16 \%$ of the total manufacturing gross output price in the four southern European countries Greece, Italy, Portugal and Spain. Felipe and Kumar (2011) and Storm and Naastepad (2014) therefore conclude that the real competitiveness problem of the southern European countries is not high costs, but the lack of non-price competitiveness and in particular the low level of complexity of their export basket. It is interesting that even the European Commission $(2012,2014)$ mentions the importance of the high degree of non-price competitiveness when explaining the good export performance of Germany as the opposite example to the southern European countries. ${ }^{5}$

This has important policy consequences because it illustrates the need for a broader view of competitiveness which takes into account factors such as the complexity of the export product structure in terms of innovative and specialized products, technological standards, the general quality of goods and services and the accuracy and engagement of business relations. Such a broader perspective should also include basic societal framework conditions, such as the technological and logistical infrastructure, the systems of skills formation and research \& development, and the culture of industrial relations (Schulten 2015). Even the ECB's Competitiveness Research Network, which was set up in 2012 and which brings together 150 economists from national central banks, calls for a broader conception of competitiveness that goes "beyond the traditional focus on costs and prices ...[by developing]... additional indicators aimed at measuring various 'non-price' factors of competitiveness" (ECB 2014: 8).

Closely linked with this narrow focus on cost competitiveness is the one-sided supply-side conception of the role of wages as cost factors which entirely neglects the much broader role of wages in generating domestic demand and in fostering social cohesion. The narrow focus on cost competitiveness also systematically overestimates the significance of exports for economic growth. Feigl and Zuckerstätter (2012) show that even in Germany, which takes a lot of pride in being "export world champion", exports actually accounted for only one third of overall demand for goods and services in 2010. Indeed, in the whole of the Eurozone, exports account for less than one fifth of overall

5. For a more detailed critique of the 'standard view' of the link between wages and economic performance which currently dominates the European and national policy-makers' crisis management based on austerity and internal devaluation, see Müller et al. (2015). 
demand (Feigl and Zuckerstätter 2012: 8). Thus, contrary to the currently dominant view, domestic demand is still more important for generating economic growth and employment than are exports.

Concerning the EU crisis management, this means that the current approach of trying to boost export growth in the southern European countries through wage cuts - in particular in the public sector - is not very promising. On the contrary, in the light of the importance of domestic demand in these countries - which according to Storm and Naastepad (2014: 12) is about three times the size of the export demand - such a policy of internal devaluation is most likely counterproductive. Any potential positive effects of wage cuts and the reduction of unit labour costs for net exports may be more than offset by the negative impact of falling real wages on domestic demand.

Against this background, it is obvious that driving down public sector wages is not the right recipe to get out of the crisis. On the contrary, a strong public sector is needed for both to boost aggregate demand and to provide a modern public infrastructure as major precondition for a competitive economy. 


\section{References}

Afonso A. and Gomes P. (2008) Interactions between private and public sector wages, Working Paper No 971, November 2008, Frankfurt, European Central Bank.

Alesina A., Ardagna S., Perotti R. and Schiantarelli F. (2002) Fiscal policy, profits and investment, American Economic Review, 92 (3), 571-589.

Alesina A. and Ardagna S. (2010) Large changes in fiscal policy: taxes vs. spending, Tax Policy and the Economy No 24, Cambridge, MA, National Bureau of Economic Research, 35-68.

Blanchard O. and Leigh D. (2013) Growth forecast errors and fiscal multipliers, IMF Working Paper WP/13/1, Washington, DC, International Monetary Fund.

Brandl B. and Traxler F. (2008) Das System der Lohnführerschaft in Österreich: eine Analyse der empirischen Relevanz, Wirtschaft und Gesellschaft, 34 (1), 9-31.

Christofides L. N. and Michael M. (2013) Exploring the public-private sector wage gap in European countries, IZA Journal of European Labor Studies 2:15. http://www.izajoels.com/content/pdf/2193-9012-2-15.pdf

De Castro F., Salto M. and Steiner H. (2013) The gap between public and private wages: new evidence for the EU, Economic Papers No 508, Brussels, European Commission.

Depalo D., Giordano R. and Papapetrou E. (2014) Public-private wage differentials and the distribution of skills across sectors, Revised paper presented at the Workshop "Government wage bill: determinants, interactions and effects" organized by the European Commission, Brussels, 11 December 2013.

European Central Bank (2014) Competitiveness research network interim report II: results in 2013 and plans for 2014. http://www.ecb.europa.eu/home/pdf/research/ compnet/CompNet_Interim_Report_Il.pdf??85f4777862dc580902dae836a387be3a

European Commission (2012) Current account surpluses in the EU, European Economy No 9/2012. http://ec.europa.eu/economy_finance/publications/european_ economy/2012/pdf/ee-2012-9_en.pdf

European Commission (2014a) Government wages and labour market outcomes, Occasional Papers No 190, Brussels, European Commission.

European Commission (2014b) Macroeconomic imbalances Germany 2014, European Economy Occasional Papers No 174, Brussels, European Commission. http://ec.europa.eu/economy_finance/publications/occasional_paper/2014/pdf/ ocp174_en.pdf

European Commission (2014c) The relationship between government and export sector wages and implications for competitiveness, Quarterly Report on the Euro Area (QREA), $13(1), 27-34$.

Eurostat (2013) Nearly $40 \%$ of persons employed by non-financial enterprises in the EU28 worked for SMEs in 2011, Eurostat Newsrelease, 175/2013, 25 November 2013, Luxembourg, Eurostat.

Feigl G. and Zuckerstätter S. (2012) Wettbewerbs(des)orientierung, Materialien zu Wirtschaft und Gesellschaft No 117, Wien, Arbeiterkammer Wien. http://www.for europe.eu/fileadmin/documents/pdf/PolicyPapers/WWWforEurope_Policy_Paper_0 02.pdf

Felipe J. and Kumar U. (2011) Unit labor costs in the eurozone: the competitiveness debate again, Working Paper No 651, New York, Levy Economics Institute of Bard College.

Giavazzi, F. and Pagano M. (1990) Can severe fiscal contractions be expansionary? Tales of two small European countries, NBER Macroeconomics Annual, 5, 75-122. 
Giordano R., Depalo D., Pereira M. C., Eugène B., Papapetrou E., Perez J.J., Reiss L. and Roter M. (2011) The public sector pay gap in a selection of euro area countries, Working Paper No 1406, Frankfurt, European Central Bank.

Grimshaw D., Rubery J. and Marino S. (2012) Public sector pay and procurement in Europe during the crisis: the challenges facing local government and the prospects for segmentation, inequalities and social dialogue. https://research.mbs.ac.uk/ european-employment/Portals/0/docs/Comparative\%20report\%20final.pdf

Guajardo J., Leigh D. and Pescatori A. (2011) Expansionary austerity: new international evidence, IMF Working Paper WP/11/158, Washington, DC, International Monetary Fund.

Hancké B. (2013) Unions, central banks, and EMU - Labour market institutions and monetary integration in Europe, Oxford, Oxford University Press.

Hernández de Cos P. and Moral-Benito E. (2013) The role of public wages in fiscal consolidation processes, Paper presented at the Workshop "Government wage bill: determinants, interactions and effects" organized by the European Commission, Brussels, 11 December 2013. http://ec.europa.eu/economy_finance/events/2013/ 20131211_ecfin_workshop/pdf/the_role_of_public_wages_in_fiscal_consolidation _processes_en.pdf

Holm-Hadulla F., Hauptmeier S. and Rother P. (2010) The impact of numerical expenditure rules on budgetary discipline over the cycle, Working Paper Series No 1169, Frankfurt, European Central Bank.

ILO (2013) Global employment trends 2013 - Recovering from a second jobs dip, Geneva, International Labour Organization.

Johnston A., Hancké B. and Pant S. (2013) Comparative institutional advantage in the European sovereign debt crisis, LEQS Paper No 66/2013, London, London School of Economics and Political Science. http://www.lse.ac.uk/europeanInstitute/LEQS/ LEQSPaper66.pdf

Krugman P. (2013) End this depression now!, New York, W.W. Norton \& Company.

Krugman P. (2014) The zombie confidence fairy, The New York Times, 10 January. http://krugman.blogs.nytimes.com/2014/01/10/the-zombie-confidence-fairy/

Lamo A., Pérez J.J. and Sánchez-Fuentes A. (2012a) Institutional determinants of publicprivate sector linkages. https://editorialexpress.com/cgi-bin/conference/ download.cgi?db_name $=x v e e p \&$ paper_id $=104$

Lamo A., Pérez J.J. and Schuknecht L. (2012b) Public or private wage leadership? An international perspective, The Scandinavian Journal of Economics, 114 (1), 228-244.

Lucifora C and Meurs D (2004) The public sector pay gap in France, Great Britain and Italy, IZA Discussion Paper No 1041, Bonn, Institute for the Study of Labor.

Müller T., Schulten T. and Zuckerstätter S. (2015) Wages and economic performance in Europe, in Van Gyes G. and Schulten T. (eds.) Wage bargaining under the new European economic governance - alternative strategies for inclusive growth, Brussels, ETUI, 259-282.

Pérez J.J. and Sánchez A.J. (2010) Is there a signalling role for public wages? Evidence for the euro area based on macro data, Working Paper No 1148, Frankfurt, European Central Bank.

Ponthieux S. and Meurs D. (2005) The gender wage gap in Europe: women, men and the public sector, Document de travail No F0502, Paris, Institut National de la Statistique et des Études Économiques. 
Schulten T. (2015) Wages, Competitiveness and Germany's Export-led Development Model, in Unger B. (ed.) The German Model - Seen by its Neighbours, Social Europe E-Book, 147-160. http://www.socialeurope.eu/wp-content/uploads/2015/04/ German-Model.pdf

Schulten T. and Brandt T. (2012) Privatisation and the Impact on Labour Relations, in Hermann C. and Flecker J. (eds.) Privatization of public services: impacts for employment, working conditions, and quality in Europe, London, Routledge, 136-152.

Schulten T. and Müller T. (2015) European economic governance and its intervention in national wage development and collective bargaining, in Lehndorff S. (ed.) Divisive integration. The triumph of failed ideas in Europe - revisited, Brussels, ETUI, 331-363.

Storm S. and Naastepad C.W.M. (2014) Europe's hunger games: Income distribution, cost competitiveness and crisis, Cambridge Journal of Economics. doi:10.1093/cje/ beu037.

Traxler F., Brandl B. and Glassner V. (2008) Pattern bargaining: an investigation into ist agency, context and evidence, British Journal of Industrial Relations, 46 (1), 33-58.

Vaughan-Whitehead D. (2013) Public sector shock in Europe: between structural reform and quantitative adjustment, in Vaughan-Whitehead (ed.) Public sector shock - The impact of policy retrenchment in Europe, Cheltenham, Edward Elgar, 1-42.

Zeilstra A. and Elbourne A (2014) Follow the leader? Public and private wages in the Netherlands, CPB Discussion Paper No 274, The Hague, CPB Netherlands Bureau for Economic Policy Analysis. 


\section{Appendix 1}

\section{Summary of findings of cross-national comparative studies on the impact of individual and occupational characteristics on public-private sector wage gap}

\begin{tabular}{|c|c|}
\hline Category & Key findings \\
\hline Country & $\begin{array}{l}\text { There seems to be a public sector pay premium in most of the Western European countries plus Slovenia and a } \\
\text { public sector pay penalty in the central and eastern European countries plus France and the Nordic countries } \\
\text { Denmark and Finland. For Lithuania, Malta, the Netherlands, Romania and the UK no significant differences were } \\
\text { found in the most recent studies by de Castro et al. (2013) and the European Commission (2014a). }\end{array}$ \\
\hline Gender & $\begin{array}{l}\text { Most studies find a public sector pay premium for female workers - However, more recent studies using SES-data } \\
\text { found no "clear-cut" and "broad-based" evidence of such a wage premium (European Commission 2014a: 18; De } \\
\text { Castro et al. 2013: 28). According to these studies female public sector workers enjoy higher earnings only in } \\
\text { Germany, Spain, Ireland, the Netherlands, Belgium, Italy and Portugal. }\end{array}$ \\
\hline Education & $\begin{array}{l}\text { There seems to be common ground that there tends to be a higher public sector wage premium for lower-skilled } \\
\text { workers with lower levels of education who normally occupy lower job positions. There also seems to be agreement } \\
\text { that in general there is a public sector pay penalty for workers with a high level of education in higher positions. }\end{array}$ \\
\hline & $\begin{array}{l}\text { However, according to the European Commission study (2014a: 19), there are some countries in which high } \\
\text { education levels show a public sector pay premium: Austria, Belgium, Cyprus, Ireland, Italy, Luxembourg, Portugal } \\
\text { and Spain. }\end{array}$ \\
\hline Age & $\begin{array}{l}\text { On average, public sector wage premium seems to be higher for older workers, but when also controlling for gender, } \\
\text { the public sector premium seems to be higher in particular for young and older female workers (De Castro 2013). }\end{array}$ \\
\hline Pay scale & $\begin{array}{l}\text { Closely linked to the finding on the impact of educational levels, the existing comparative studies suggest that } \\
\text { there is a more general public sector wage premium for workers at the bottom of the wage scale. }\end{array}$ \\
\hline Sub-sector & $\begin{array}{l}\text { Giordano et al. ( } 2011 \text { ) found that within the public sector, the pay premium tends to be higher in education and } \\
\text { public administration than for instance in the health sector. }\end{array}$ \\
\hline Type of contract & $\begin{array}{l}\text { The European Commission (2014a) study found some evidence that there are higher wages paid in the public } \\
\text { sector for workers with permanent and fixed-term contracts and for apprentices. }\end{array}$ \\
\hline Type of wage & $\begin{array}{l}\text { Giordano et al. ( } 2011 \text { ) found that the difference between public and private sector pay decreases when } \\
\text { considering monthly wages as opposed to hourly wages and when confining the analysis to large private firm. }\end{array}$ \\
\hline Wage setting & $\begin{array}{l}\text { The European Commission study found some evidence the public sector wage premium tend to be lower in countries } \\
\text { in which wages are set through collective bargaining rather than through unilateral decisions/legislative acts. }\end{array}$ \\
\hline Trade union power & $\begin{array}{l}\text { Those studies which considered the impact of institutional factors such as trade unions' bargaining power did not } \\
\text { find a significant correlation with the size of the wage differential (for instance Giordano et al. 2011). }\end{array}$ \\
\hline
\end{tabular}





\section{Appendix 2}

\section{Country-specific overview of wage developments in public and private sector 2001-2013}

\section{Belgium}

Wage developments in public and private sector 2001-2013

Over the whole period 2001-2013, there was an almost parallel development of private and public sector wages. While public sector wage growth was slightly above that in the private sector in 2003-2006, private sector wages grew somewhat faster from 2009 onwards. In 2013 the relation was again reversed with a higher growth of wages in the public sector.
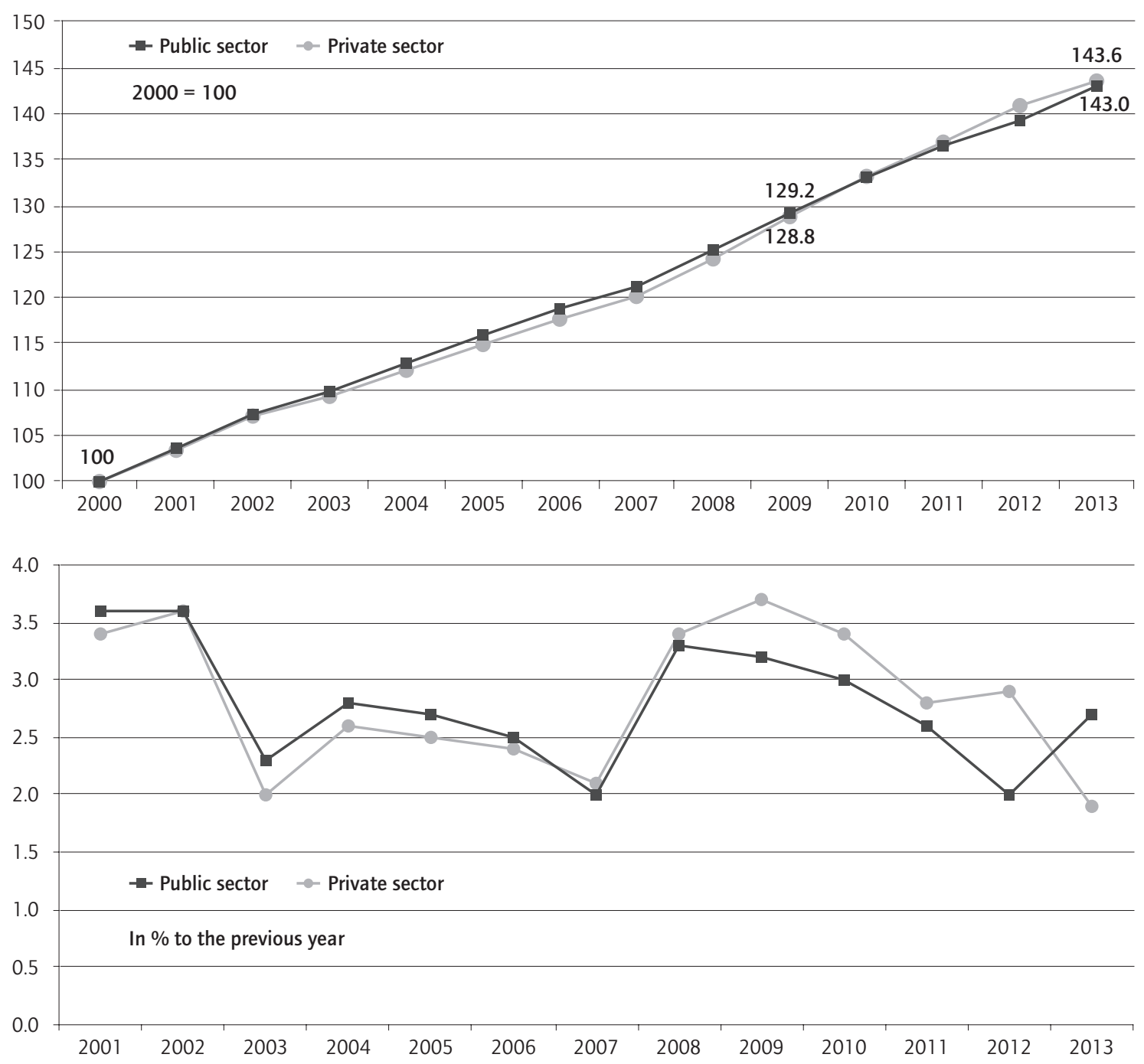

Private Sector: NACE Code B-N (Business economy)

Public Sector: NACE Code O-S (Public administration and defence; compulsory social security; education; human health and social work activities; arts, entertainment and recreation)

Source: Eurostat 


\section{Bulgaria}

\section{Wage developments in public and private sector 2001-2013}

Over the whole period 2001-2013, public sector wages grew significantly faster than in the private sector. This was mainly due to a much higher growth in the first half of the 2000s. Between 2005 and 2009, there was an almost parallel development of private and public sector wages with the former being slightly above the latter. In the most recent years 2011-2013 private sector wages grew again somewhat faster than in the public sector.

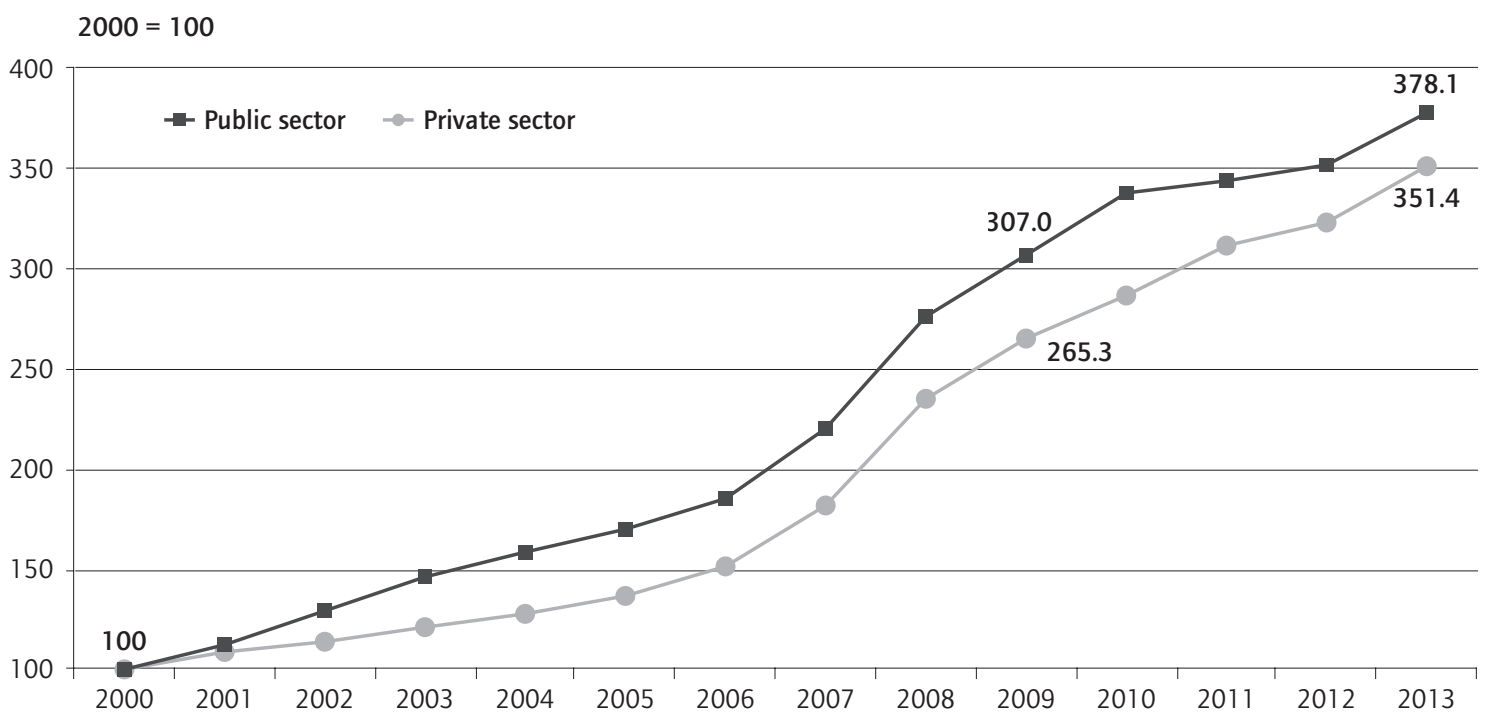

In $\%$ to the previous year

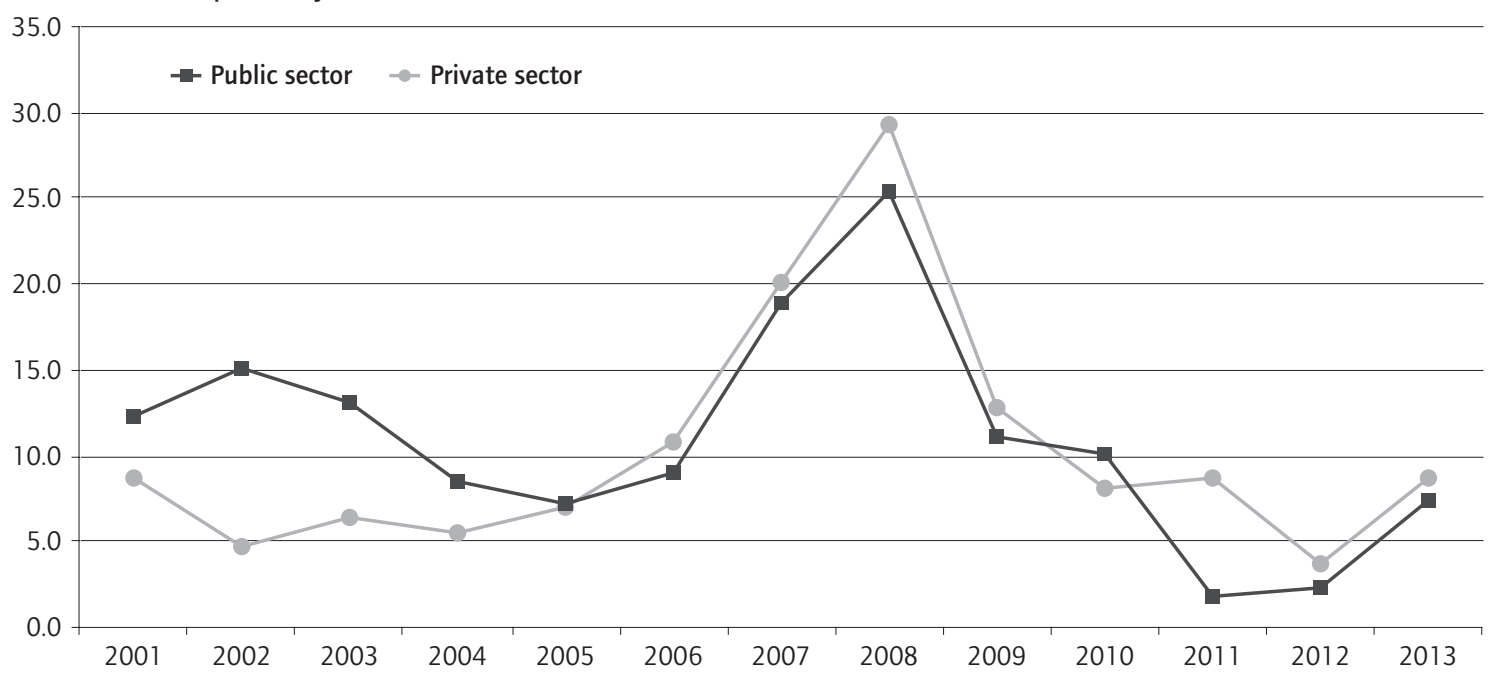

Private Sector: NACE Code B-N (Business economy)

Public Sector: NACE Code O-S (Public administration and defence; compulsory social security; education; human health and social work activities; arts, entertainment and recreation)

Source: Eurostat 


\section{Czech Republic}

Wage developments in public and private sector 2001-2013

Over the whole period 2001-2013, public sector wages grew somewhat faster than in the private sector. This was mainly the result of a much higher growth rate in the first half of the 2000s. Since 2006, private sector wages as a rule grew somewhat faster than in the public sector with the exception of the crisis year 2009 and most recently in 2013.

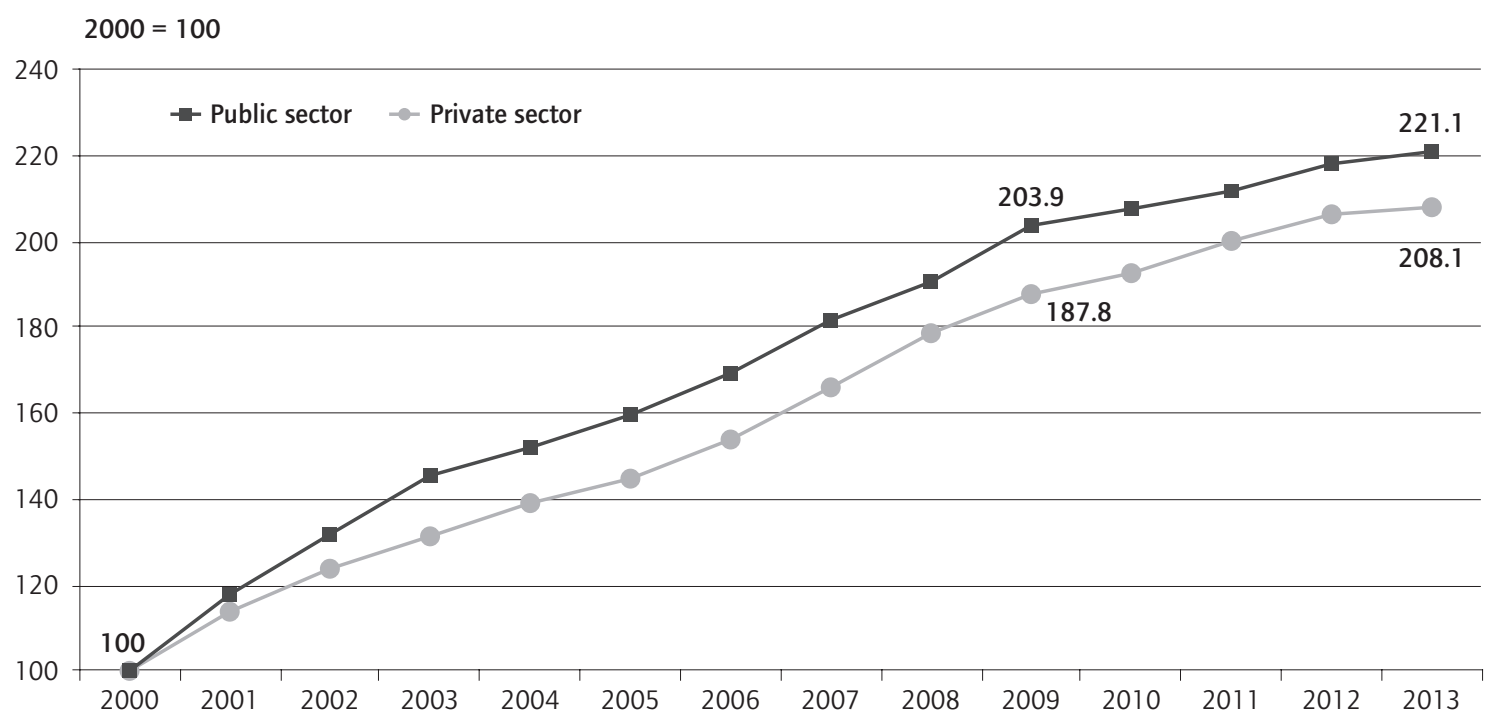

In $\%$ to the previous year

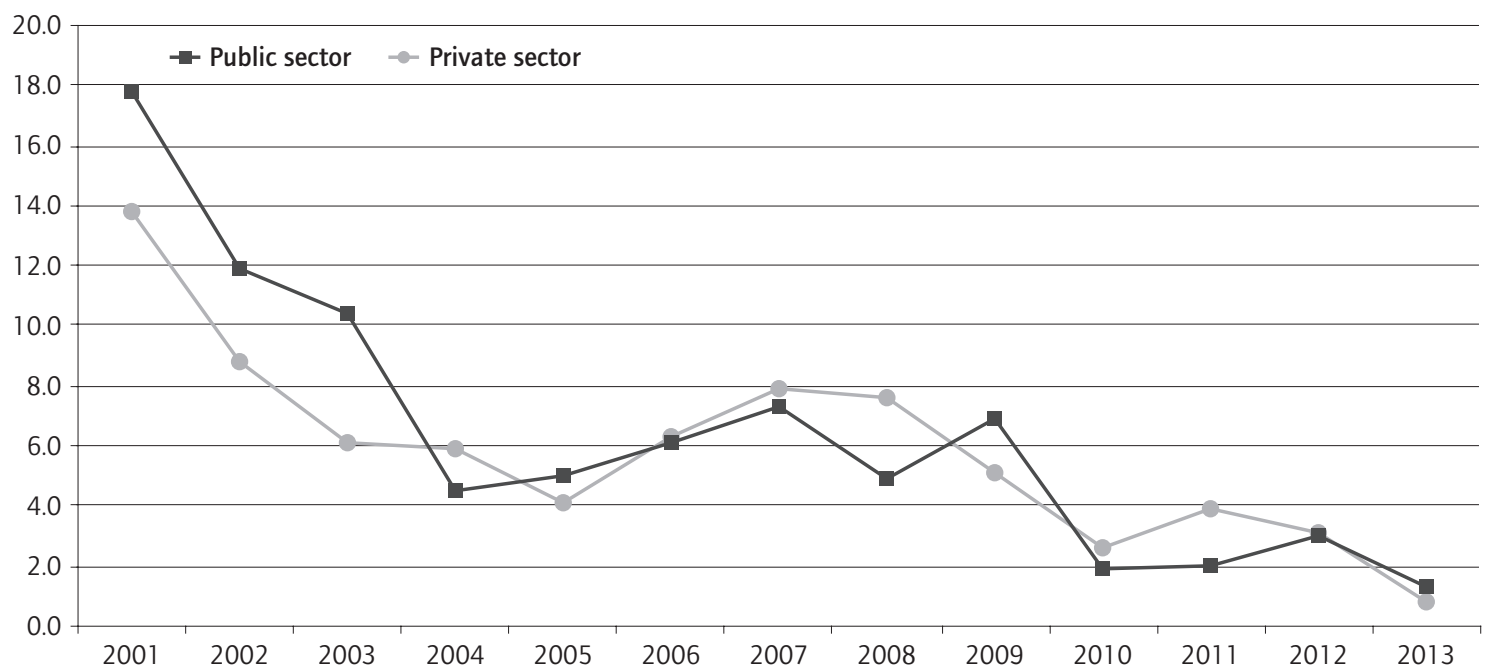

Private Sector: NACE Code B-N (Business economy)

Public Sector: NACE Code O-S (Public administration and defence; compulsory social security; education; human health and social work activities; arts, entertainment and recreation)

Source: Eurostat 


\section{Cyprus}

Wage developments in public and private sector 2001-2013

Between 2001 and 2008, public and private sector wages showed almost a parallel development. From 2009 to 2011, private sector wages grew somewhat faster. Since 2011 both private and public sector wages declined strongly, whereby the fall was much faster in the public sector.

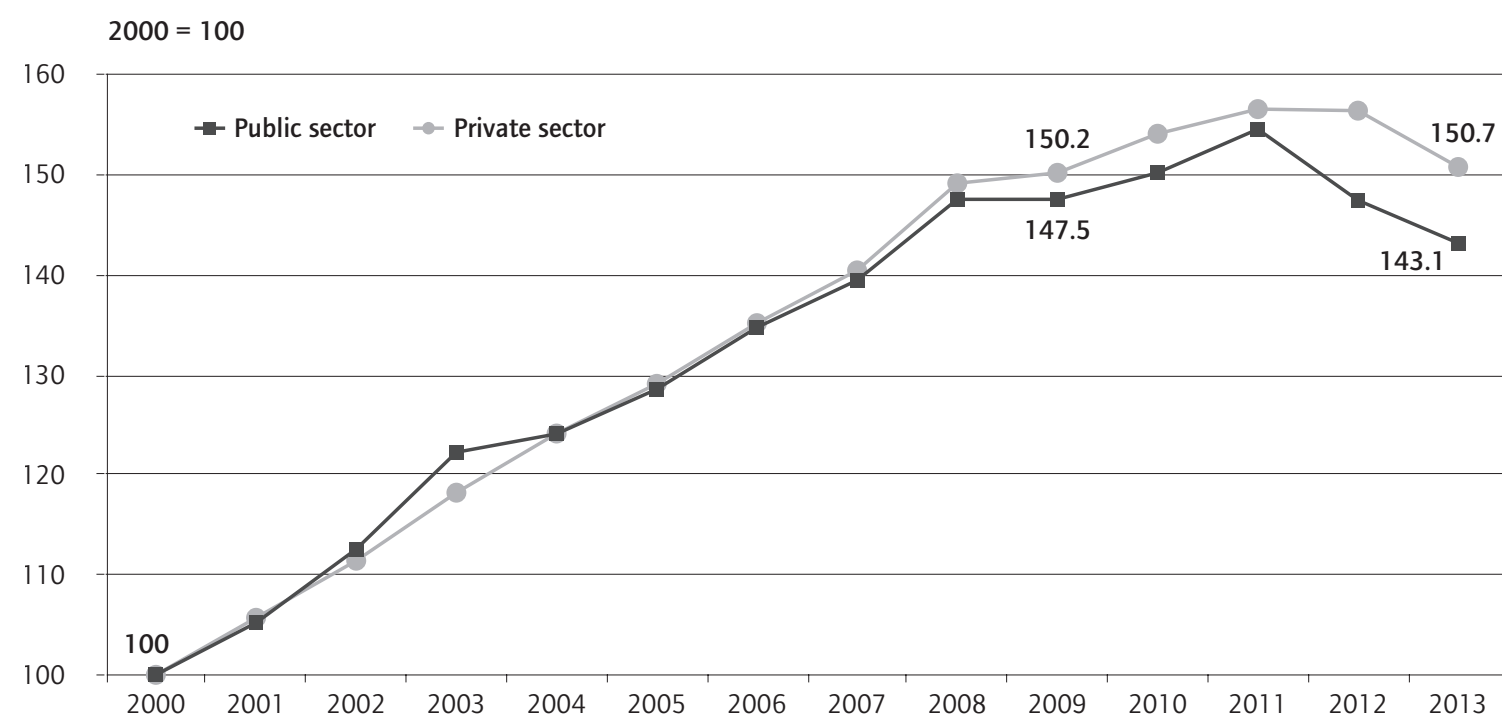

In $\%$ to the previous year

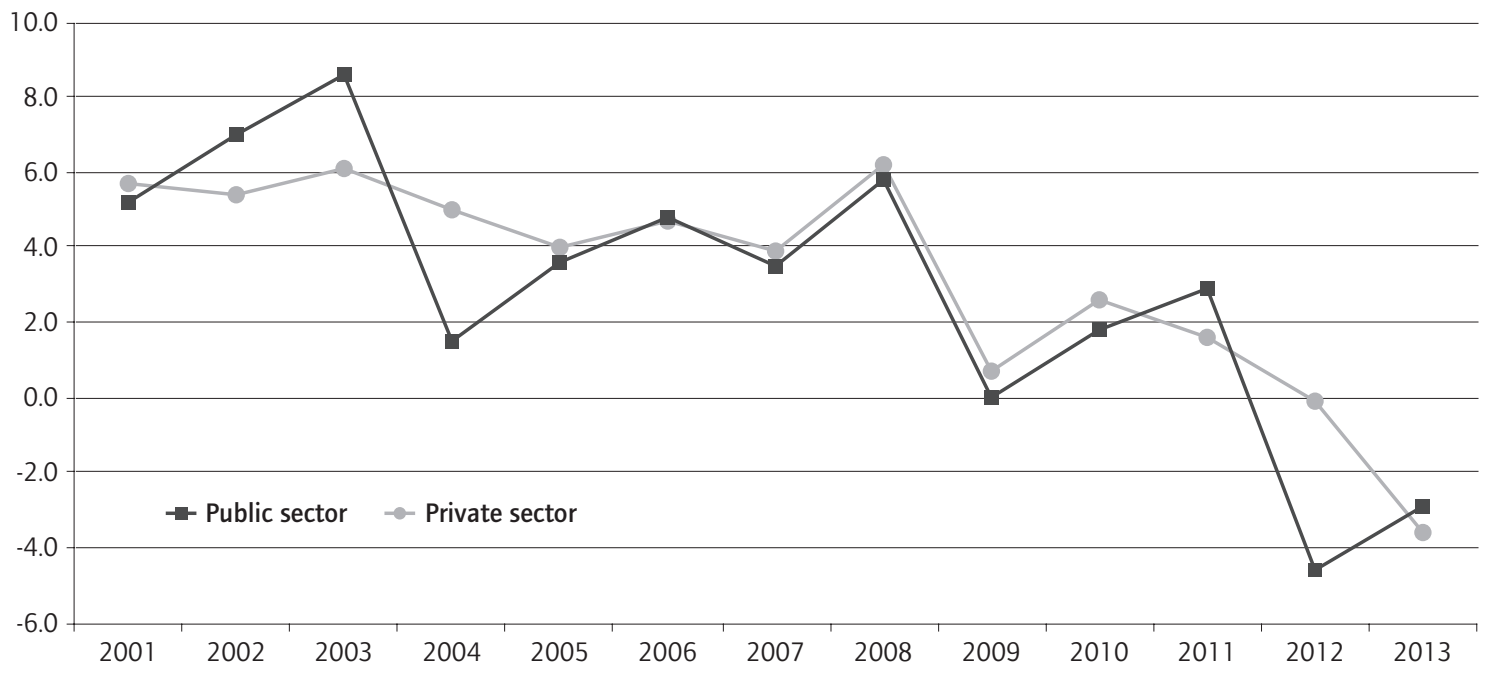

Private Sector: NACE Code B-N (Business economy)

Public Sector: NACE Code O-S (Public administration and defence; compulsory social security; education; human health and social work activities; arts, entertainment and recreation)

Source: Eurostat 


\section{Estonia}

\section{Wage developments in public and private sector 2001-2013}

Between 2001 and 2007, public and private sector wages showed almost a parallel development. Between 2008 and 2010 there was a decline in both private and public sector wages. Since then private sector wages grew somewhat faster than wages in the public sector.

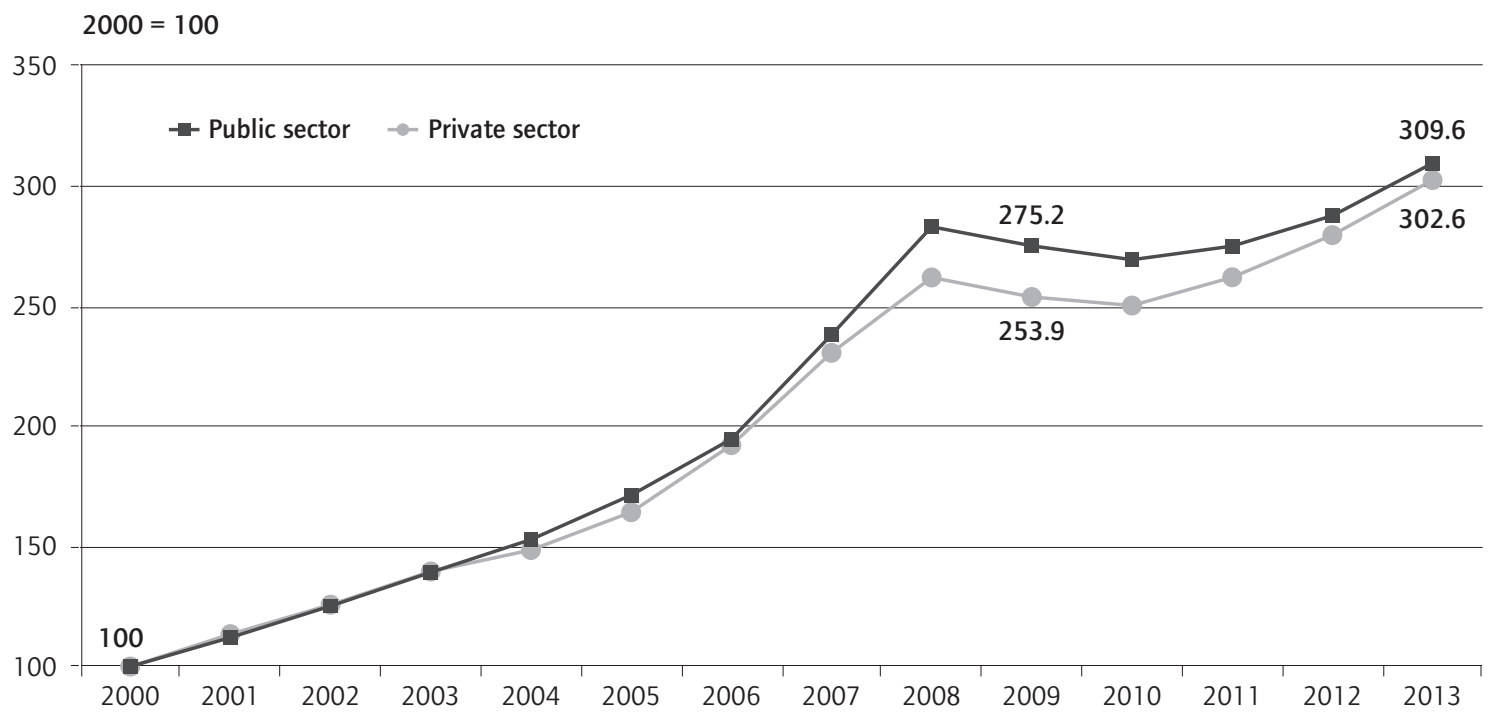

In $\%$ to the previous year

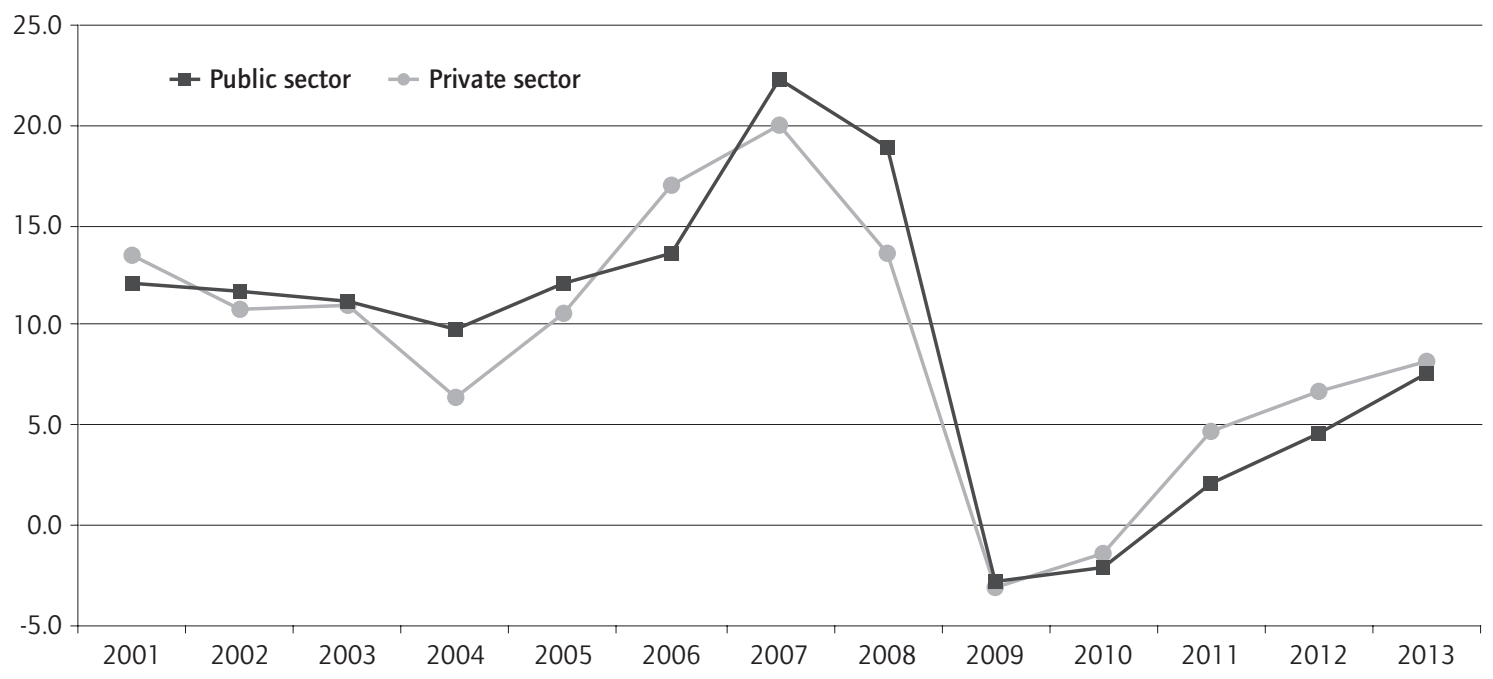

Private Sector: NACE Code B-N (Business economy)

Public Sector: NACE Code O-S (Public administration and defence; compulsory social security; education; human health and social work activities; arts, entertainment and recreation)

Source: Eurostat 


\section{Finland}

\section{Wage developments in public and private sector 2001-2013}

Over the whole period 2001-2013, wages grew significantly faster in the private sector than in the public sector. This was mainly due to much higher wage increases between 2001 and 2007. The public sector caught up, however, to a certain extent in 2008 and 2012. In 2013, public sector wages again grew much slower than private sector wages.

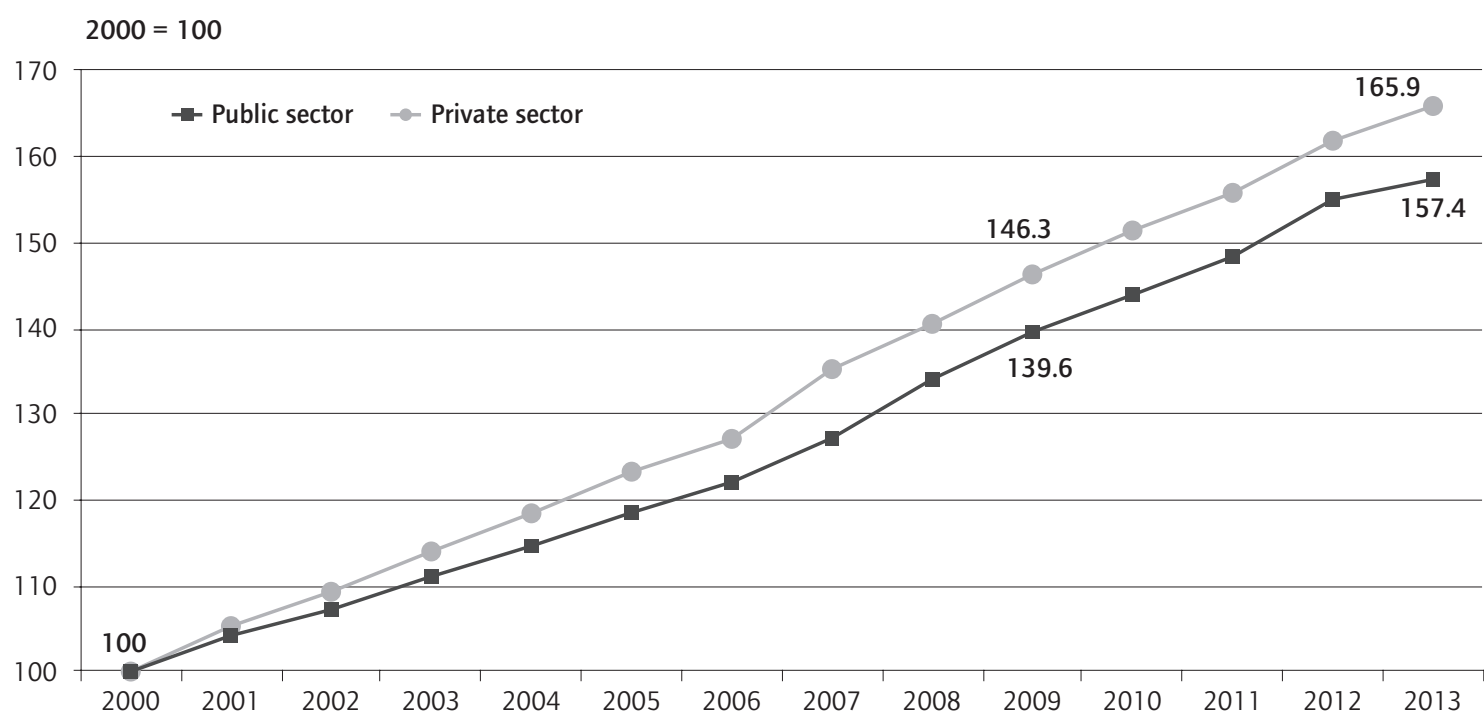

In $\%$ to the previous year

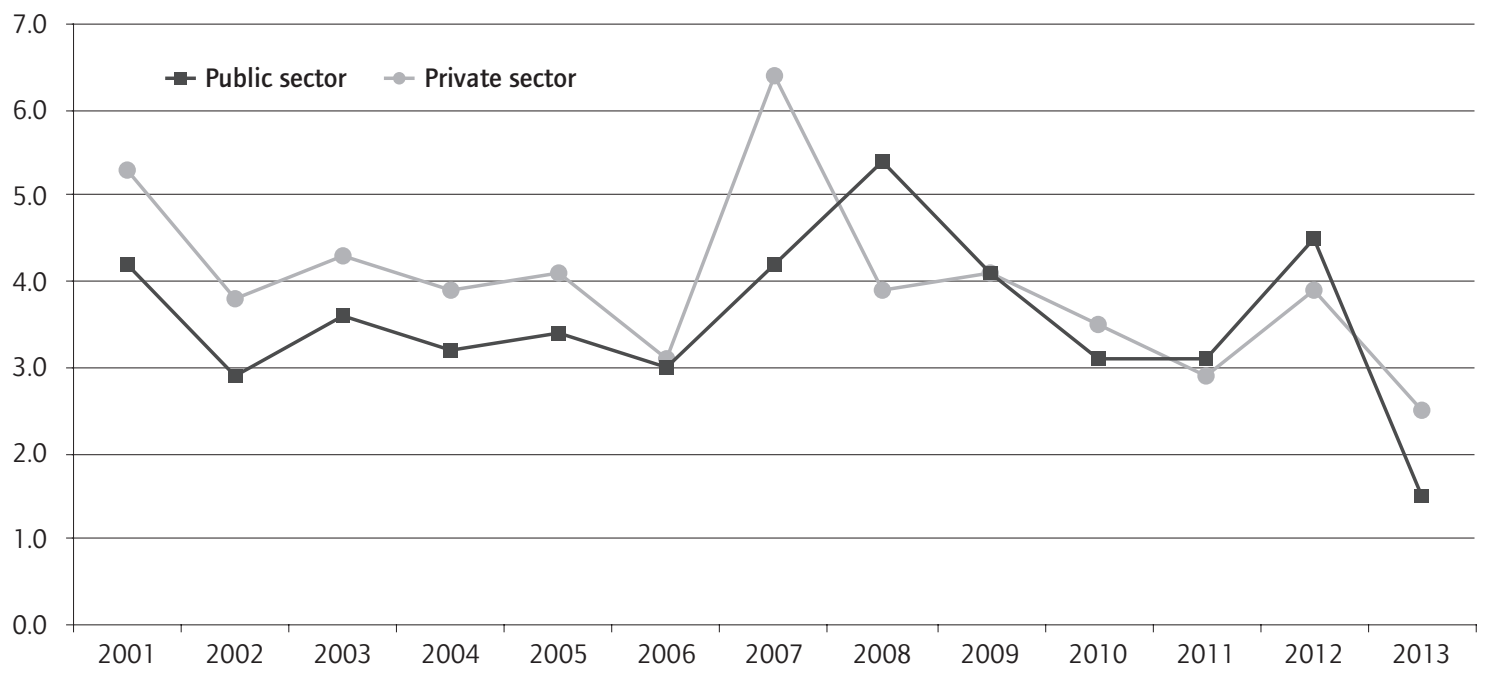

Private Sector: NACE Code B-N (Business economy)

Public Sector: NACE Code O-S (Public administration and defence; compulsory social security; education; human health and social work activities; arts, entertainment and recreation)

Source: Eurostat 


\section{Germany}

Wage developments in public and private sector 2001-2013

Over the whole period 2001-2013, the increases of private sector wages were significantly higher than in the public sector. There were only two years (2009 and 2013) in which public sector wage growth exceeded that of the private sector.

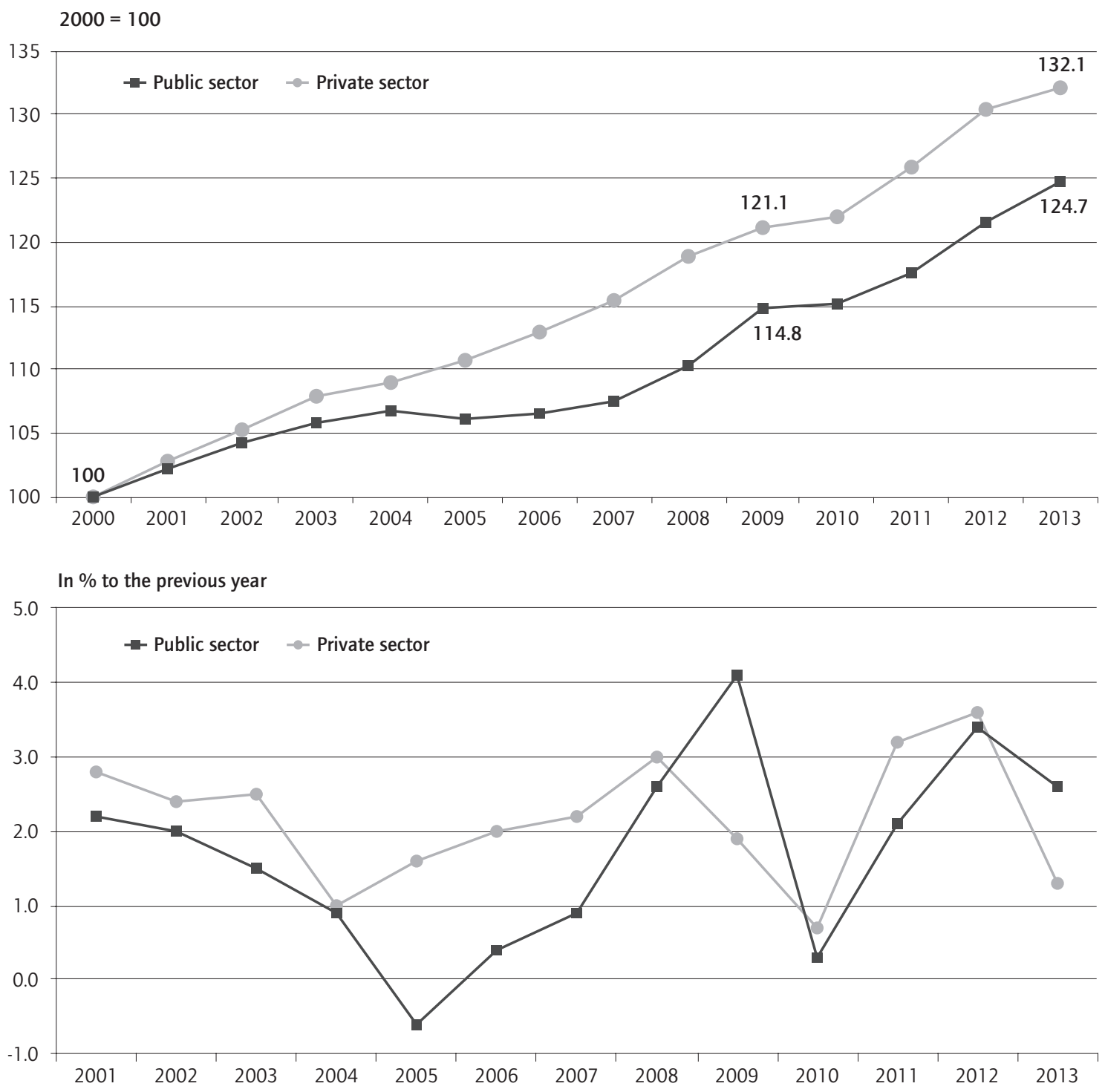

Private Sector: NACE Code B-N (Business economy)

Public Sector: NACE Code O-S (Public administration and defence; compulsory social security; education; human health and social work activities; arts, entertainment and recreation)

Source: Eurostat 


\section{Greece}

\section{Wage developments in public and private sector 2001-2013}

Between 2001 and 2008, public sector wage increases strongly exceeded those of the private sector with the exception of the year 2006. Since 2009, both public and private sector wages showed a sharp decline, whereby the drop in public sector wages was much sharper.

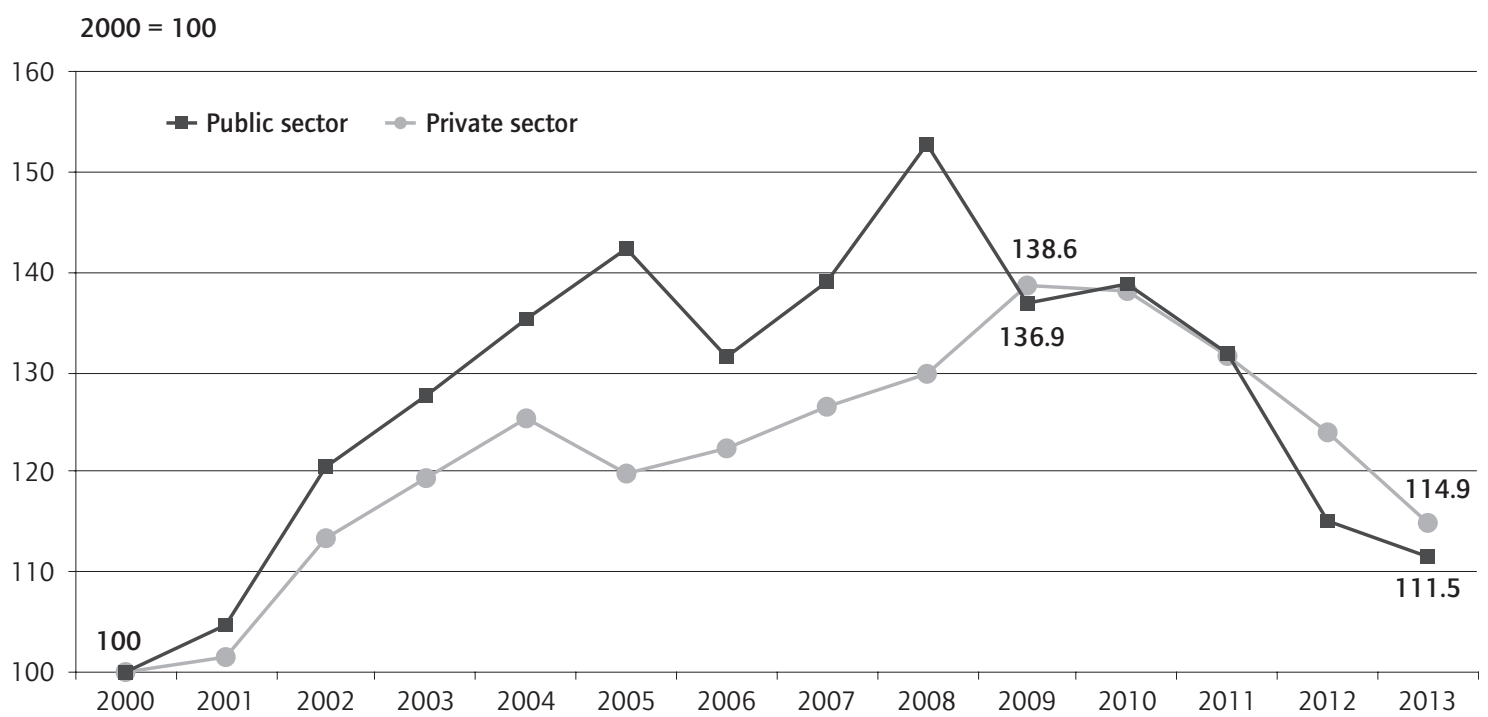

In $\%$ to the previous year

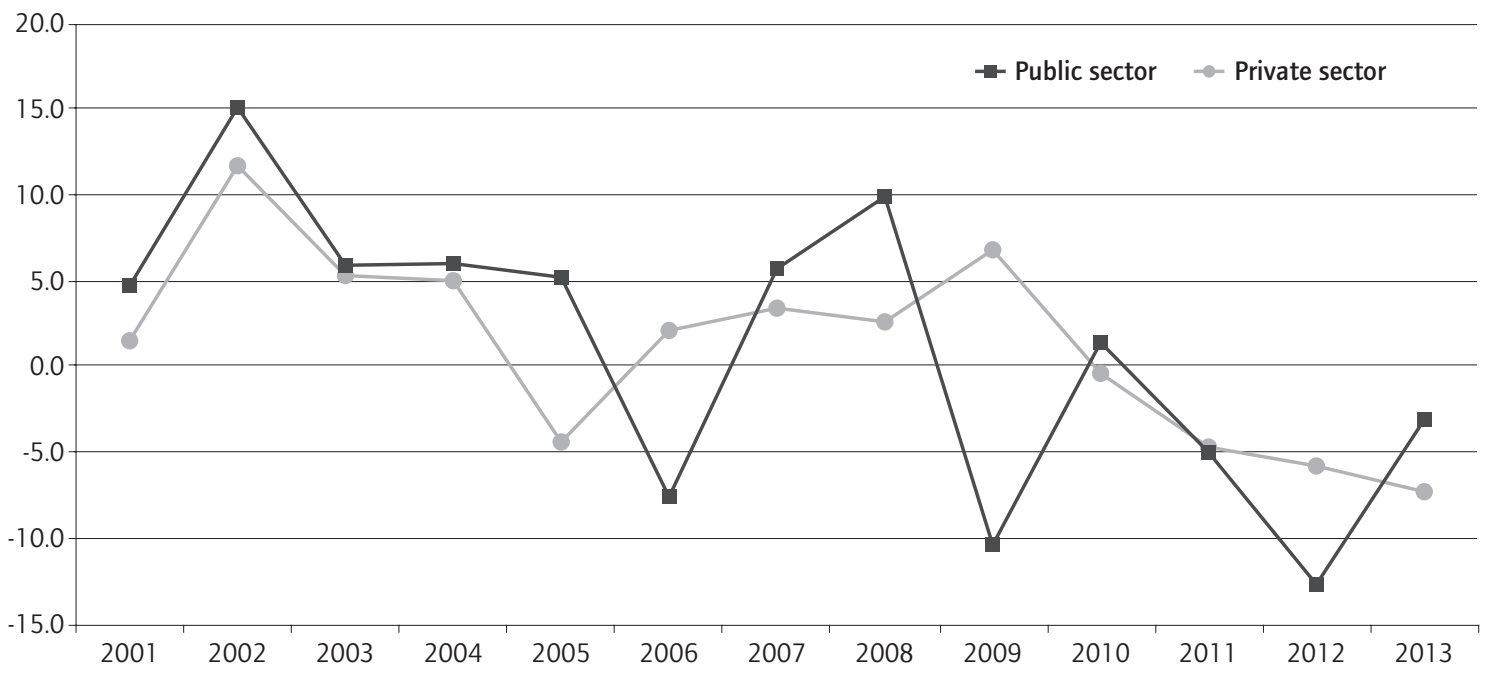

Private Sector: NACE Code B-N (Business economy)

Public Sector: NACE Code O-S (Public administration and defence; compulsory social security; education; human health and social work activities; arts, entertainment and recreation)

Source: Eurostat 


\section{Hungary}

Wage developments in public and private sector 2001-2013

Between 2001 and 2008, public sector wages grew much faster than wages in the private sector which was mainly due to extraordinary strong increases in the years 2001-2003. In 2009 and 2010, the public sector faced significant wage drops, while in the private sector wages continued to grow and in 2013 caught up with the public sector.

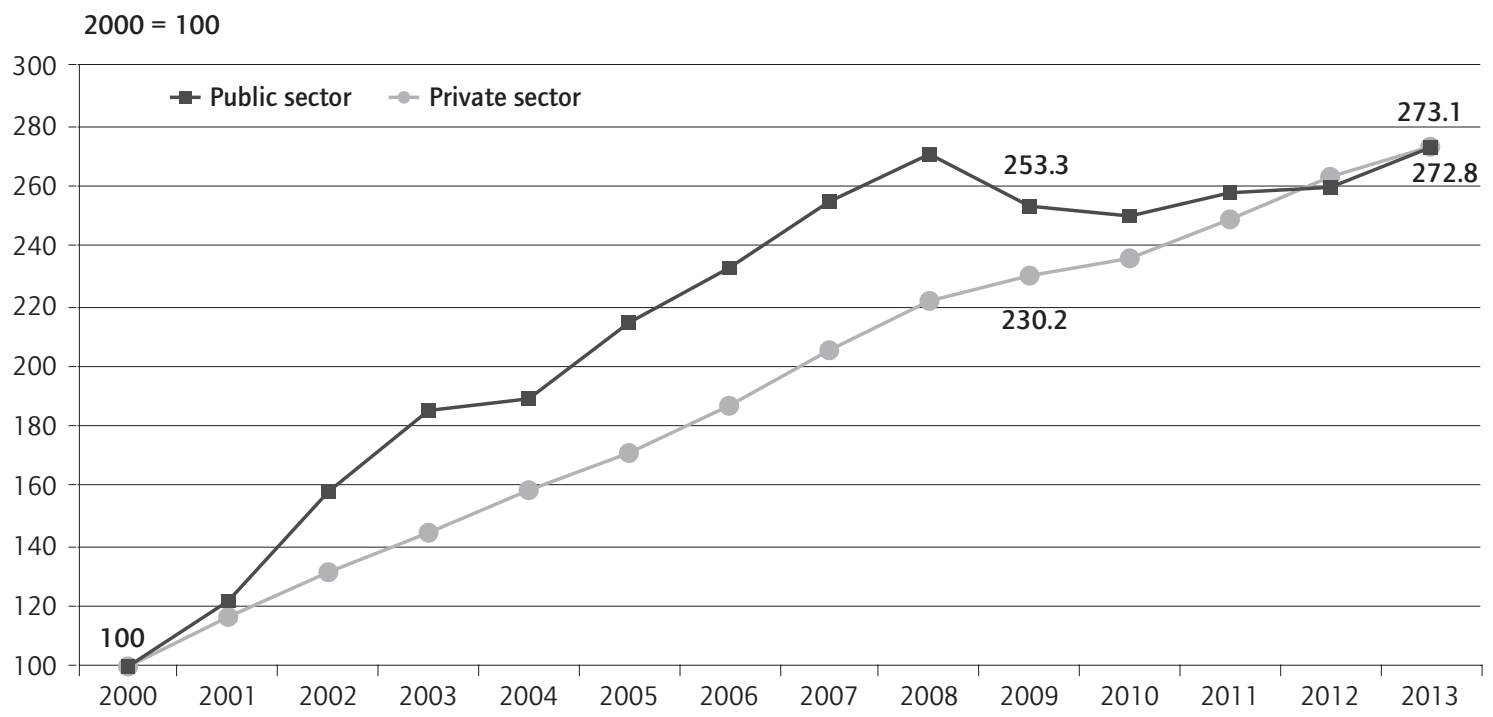

In $\%$ to the previous year

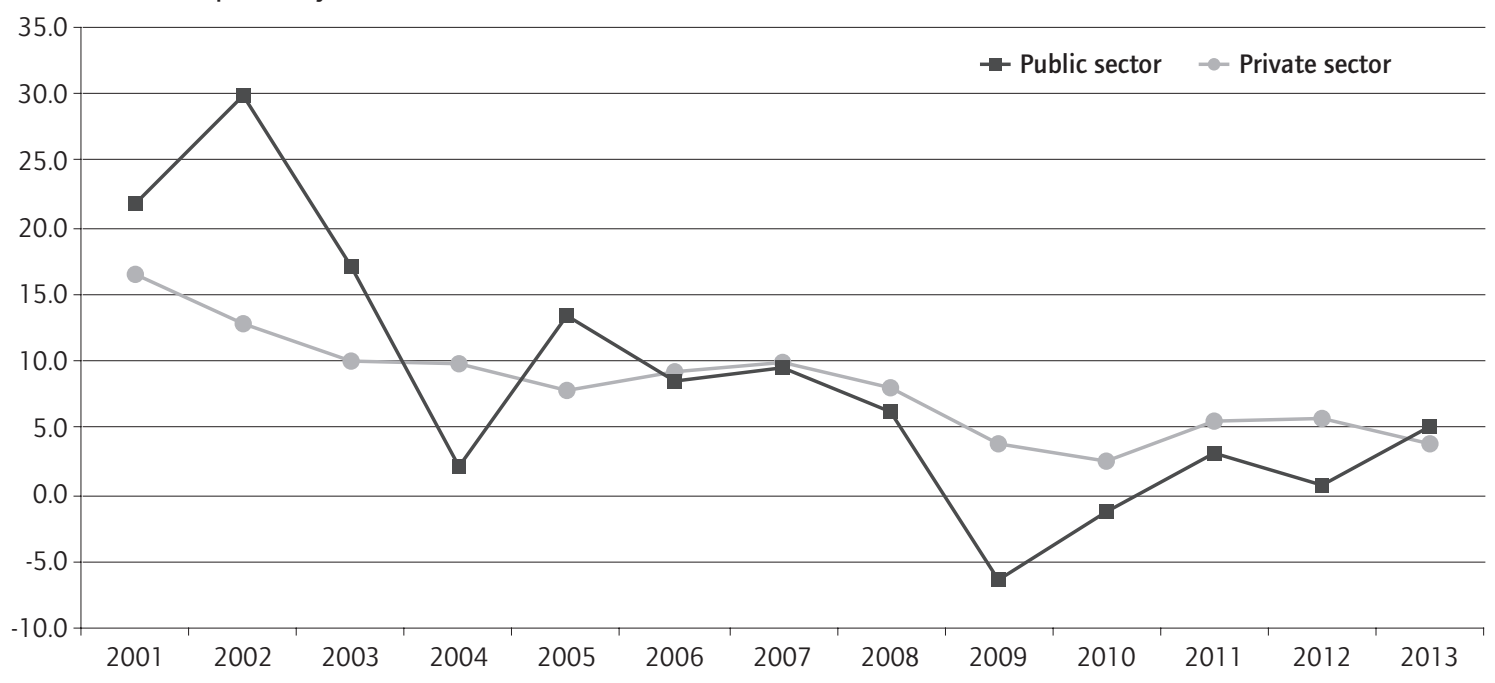

Private Sector: NACE Code B-N (Business economy)

Public Sector: NACE Code O-S (Public administration and defence; compulsory social security; education; human health and social work activities; arts, entertainment and recreation)

Source: Eurostat 


\section{Ireland}

\section{Wage developments in public and private sector 2001-2013}

Between 2001 and 2009, public sector wage growth was slightly above that of the private sector. This was mainly due to a very strong increase in the years 2004 and 2005. After a relatively strong decrease in 2010, public sector wages have continued a downward trend, while private sector wage growth remained slightly positive.

$2000=100$

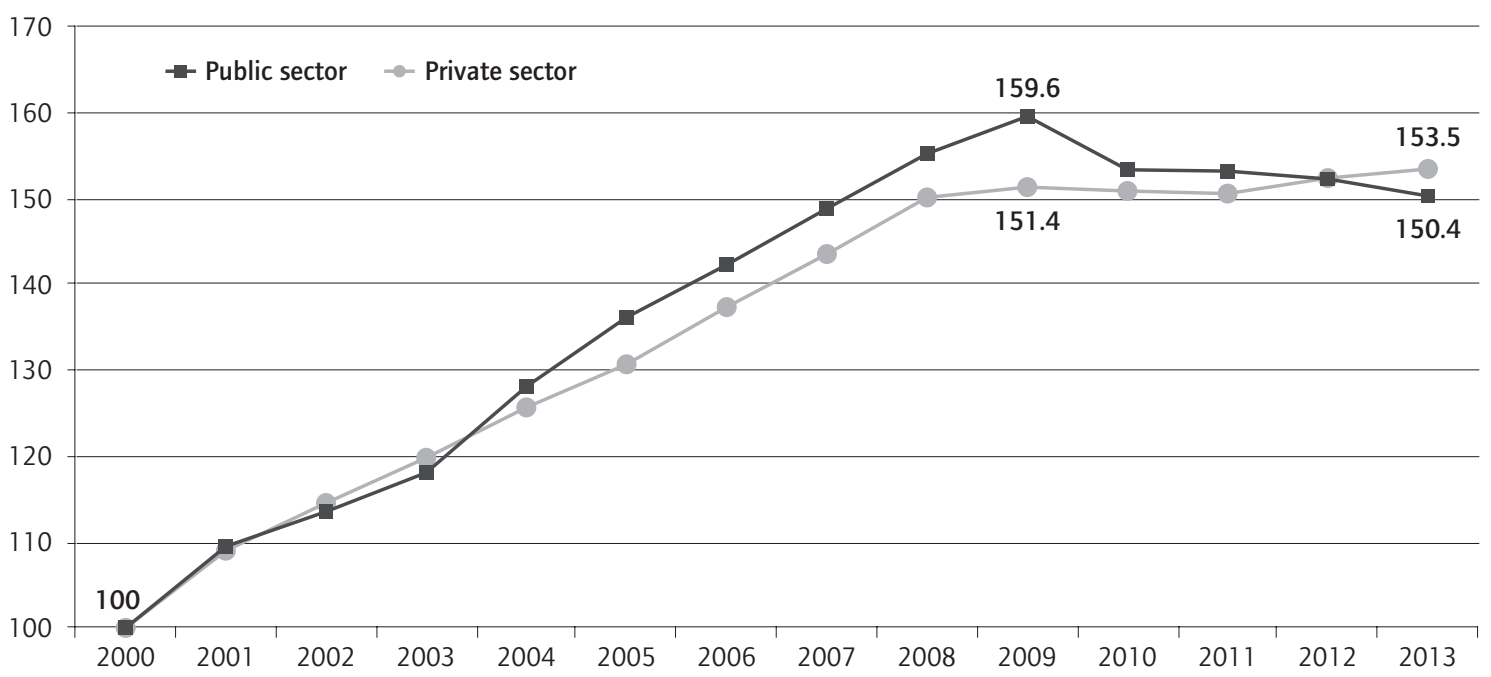

In $\%$ to the previous year

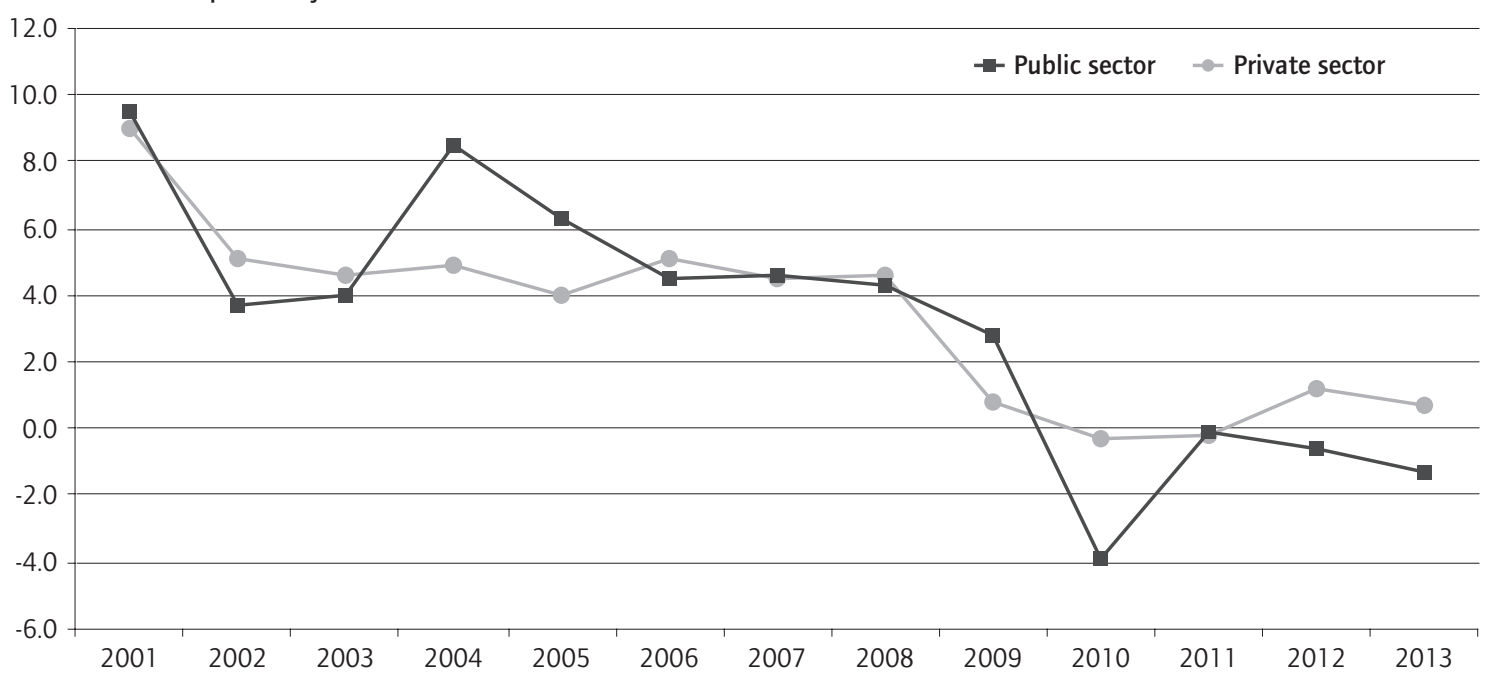

Private Sector: NACE Code B-N (Business economy)

Public Sector: NACE Code O-S (Public administration and defence; compulsory social security; education; human health and social work activities; arts, entertainment and recreation)

Source: Eurostat 


\section{Italy}

Wage developments in public and private sector 2001-2013

Between 2001 and 2007, public sector wage increases strongly exceeded those of the private sector. From 2007 onwards the picture reversed and private sector wage growth was faster than in the public sector. In 2001 and 2010, public sector wages showed a relatively strong decrease.
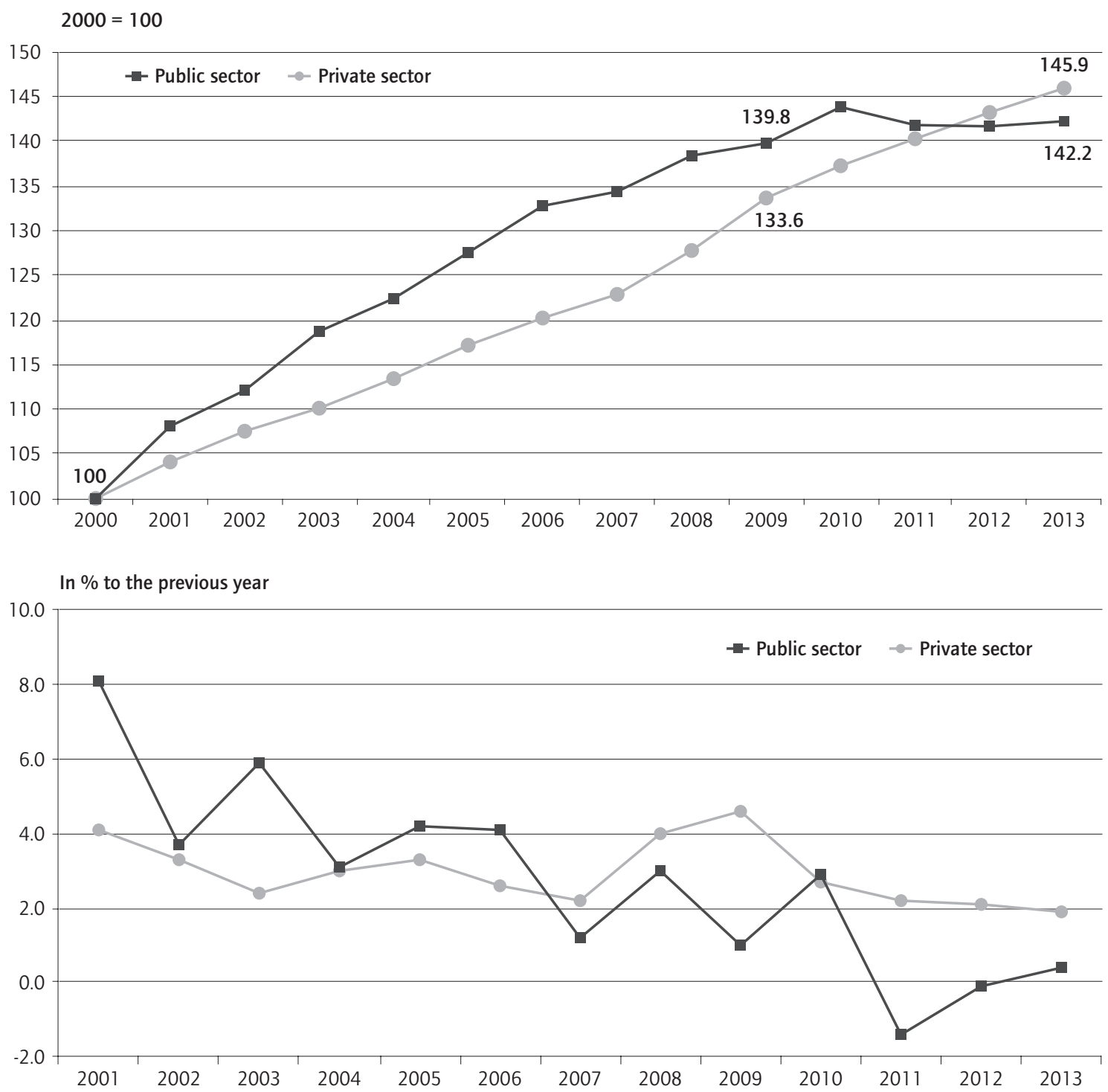

Private Sector: NACE Code B-N (Business economy)

Public Sector: NACE Code O-S (Public administration and defence; compulsory social security; education; human health and social work activities; arts, entertainment and recreation)

Source: Eurostat 


\section{Latvia}

\section{Wage developments in public and private sector 2001-2013}

Between 2001 and 2008, public and private sector wages showed almost a parallel development with a slightly stronger growth in the public sector. Afterwards, in 2009 and 2010, wages decreased in both sectors, while the drop was much more pronounced in the public sector. Recently, in 2011-2013, wages have increased again in both sectors on relatively equal terms.

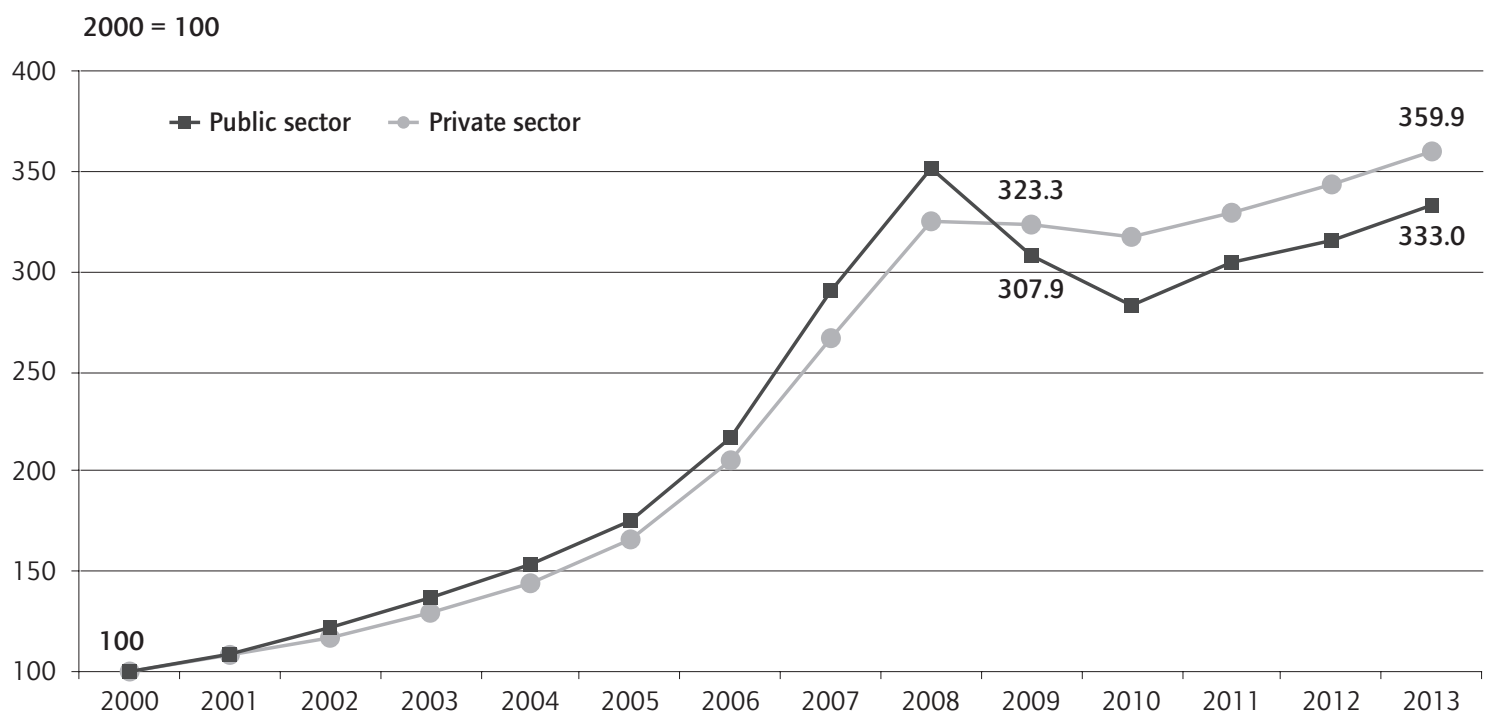

In $\%$ to the previous year

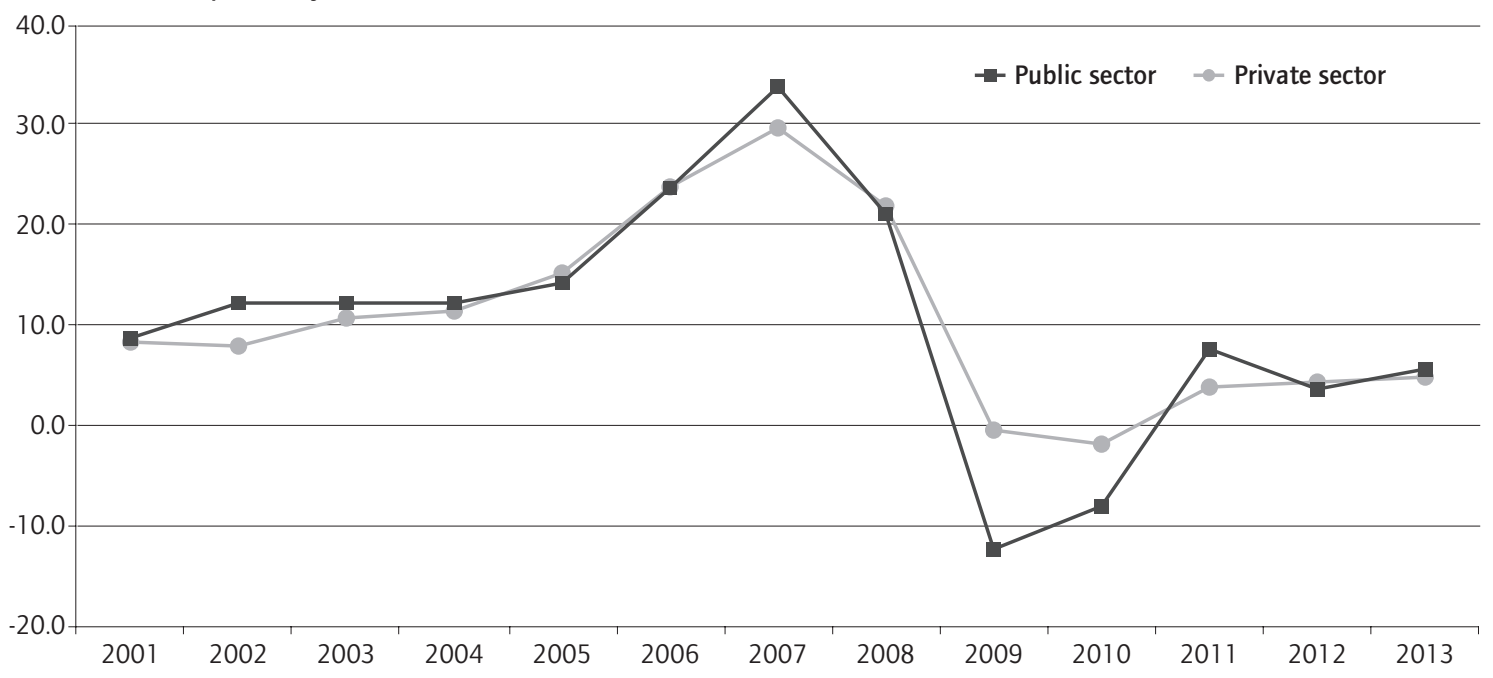

Private Sector: NACE Code B-N (Business economy)

Public Sector: NACE Code O-S (Public administration and defence; compulsory social security; education; human health and social work activities; arts, entertainment and recreation)

Source: Eurostat 


\section{Lithuania}

\section{Wage developments in public and private sector 2001-2013}

Between 2001 and 2008, public and private sector wages showed almost a parallel development with a slightly faster growth in the private sector. Afterwards, in 2009 and 2010, wages decreased in both sectors, with a much more pronounced drop in the private sector. In the recent years, 2011-2013, wages have increased again in both sectors, while private sector wages have somewhat caught up again.

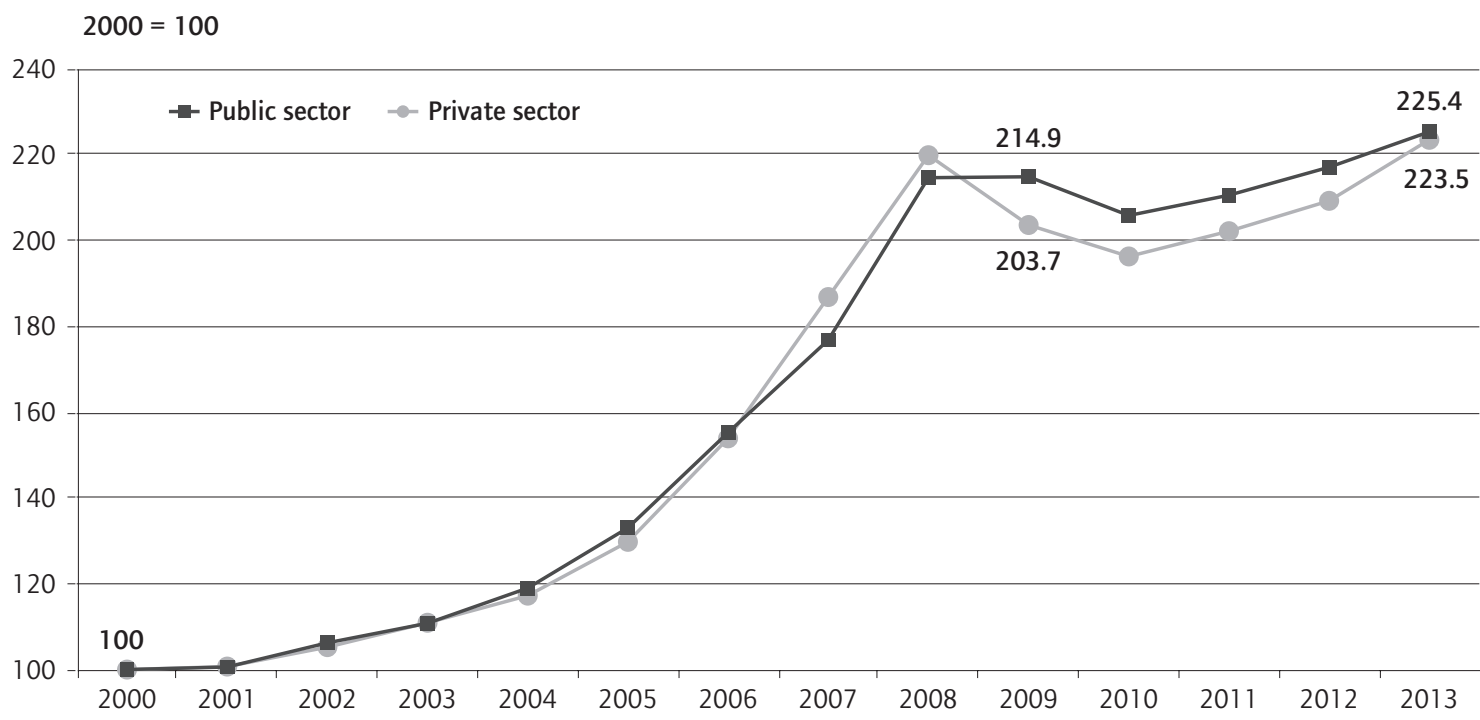

In $\%$ to the previous year

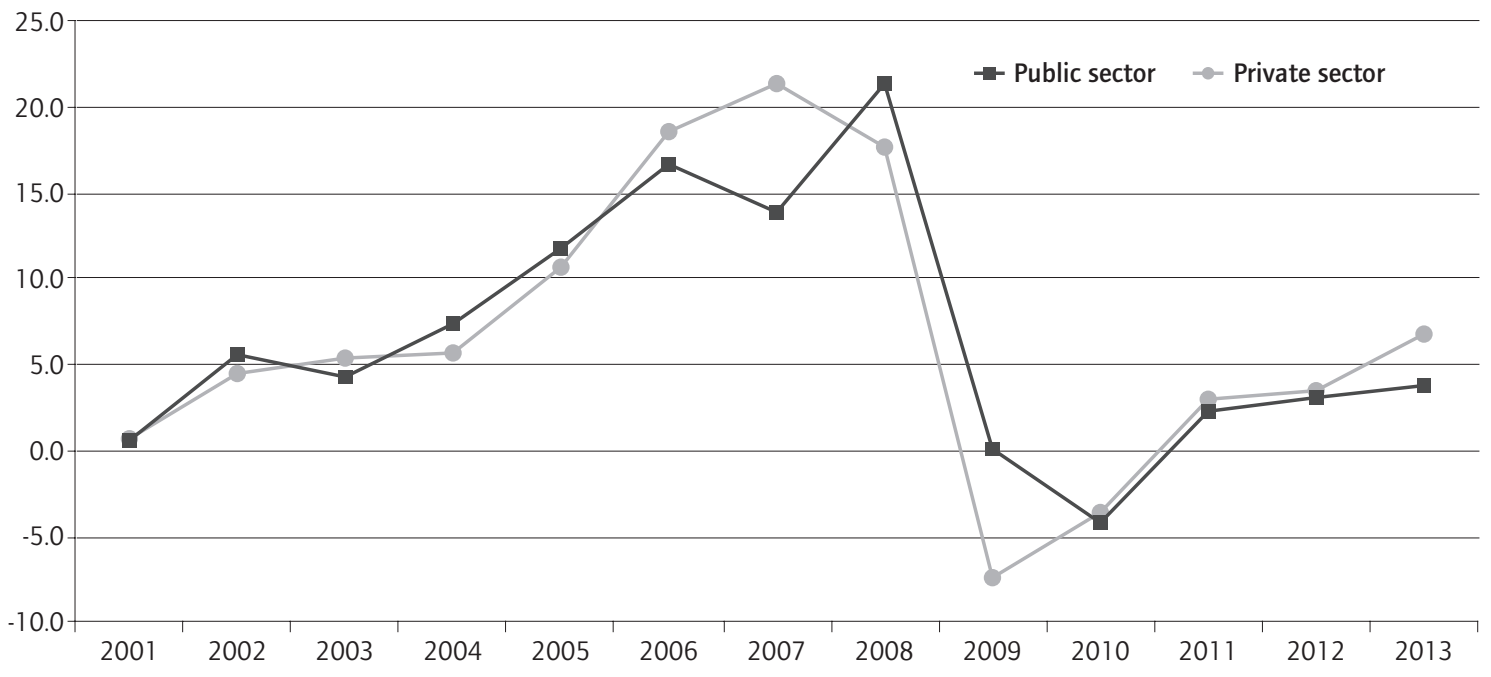

Private Sector: NACE Code B-N (Business economy)

Public Sector: NACE Code O-S (Public administration and defence; compulsory social security; education; human health and social work activities; arts, entertainment and recreation)

Source: Eurostat 


\section{Luxembourg}

Wage developments in public and private sector 2001-2013

Over the whole period 2001-2013, there was an almost parallel development of private and public sector wages. Only in the most recent period between 2011 and 2013, public sector wage growth lagged somewhat behind that of the private sector.

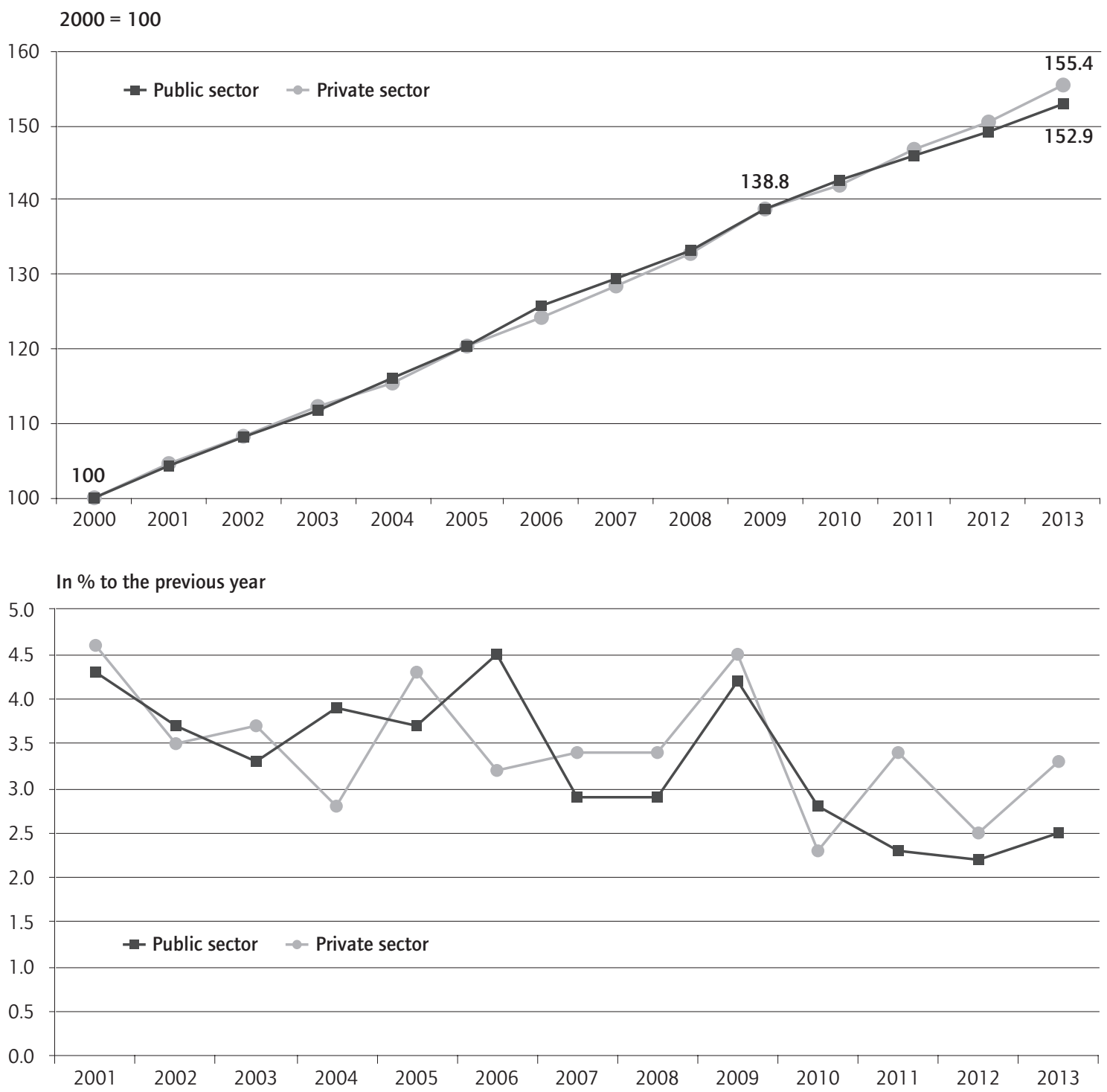

Private Sector: NACE Code B-N (Business economy)

Public Sector: NACE Code O-S (Public administration and defence; compulsory social security; education; human health and social work activities; arts, entertainment and recreation)

Source: Eurostat 


\section{Malta}

Wage developments in public and private sector 2001-2013

Over the whole period 2001-2013, there was a significantly higher wage growth in the public than in the private sector. There was no clear pattern in the annual wage growth because wage leadership changed quite frequently between public and private sector.

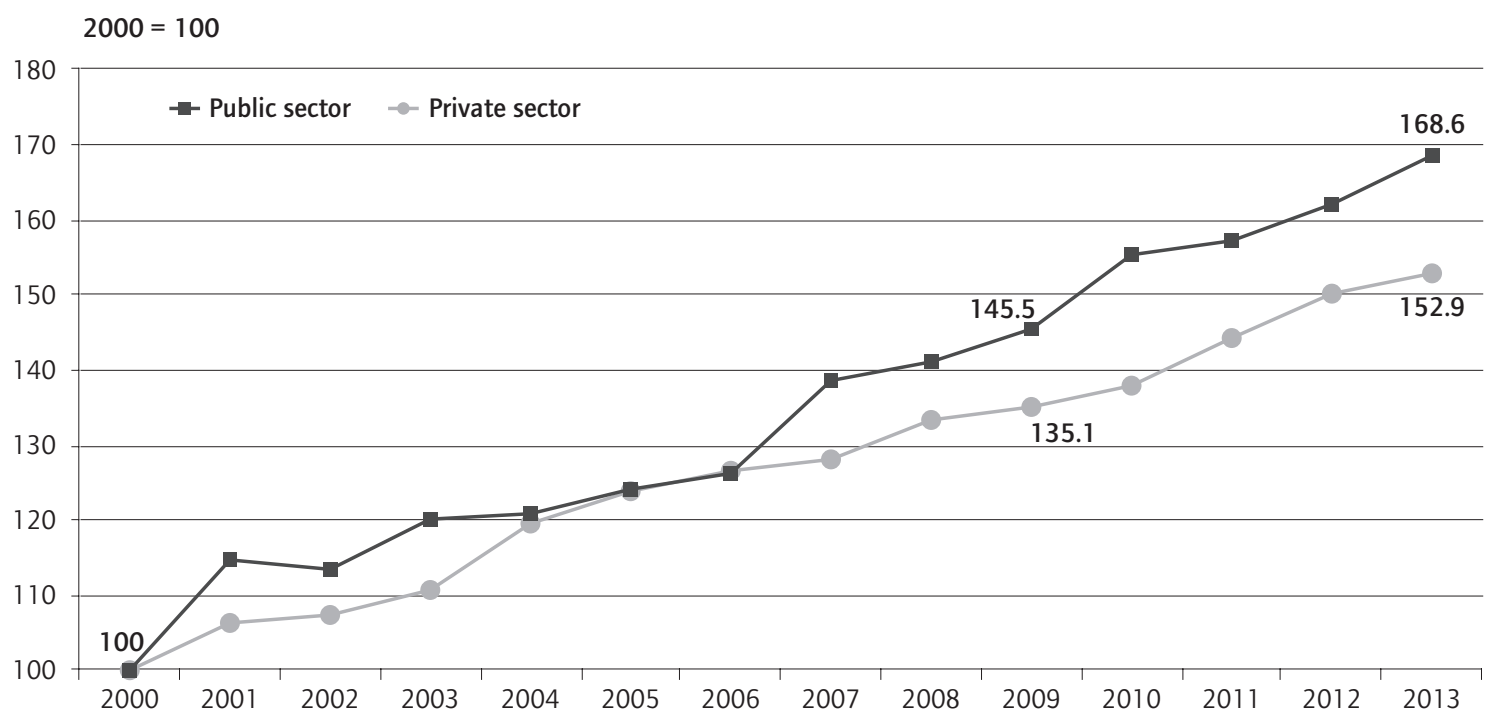

In $\%$ to the previous year

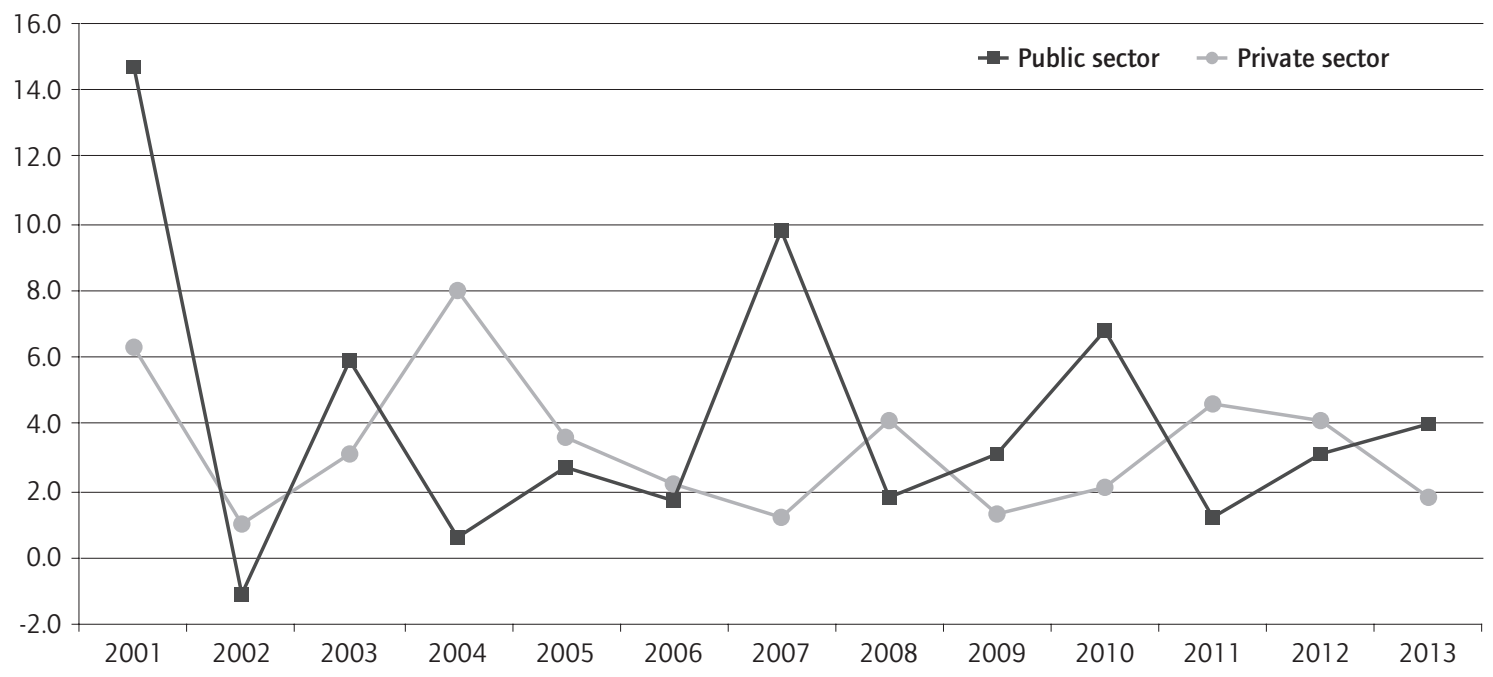

Private Sector: NACE Code B-N (Business economy)

Public Sector: NACE Code O-S (Public administration and defence; compulsory social security; education; human health and social work activities; arts, entertainment and recreation)

Source: Eurostat 


\section{Netherlands}

\section{Wage developments in public and private sector 2001-2013}

Over the whole period 2001-2013, there was an almost parallel development of private and public sector wages. Until 2009, private sector wages grew slightly stronger than in the public sector, while after that public sector wages grew somewhat faster. In 2013, the private sector has caught up again.

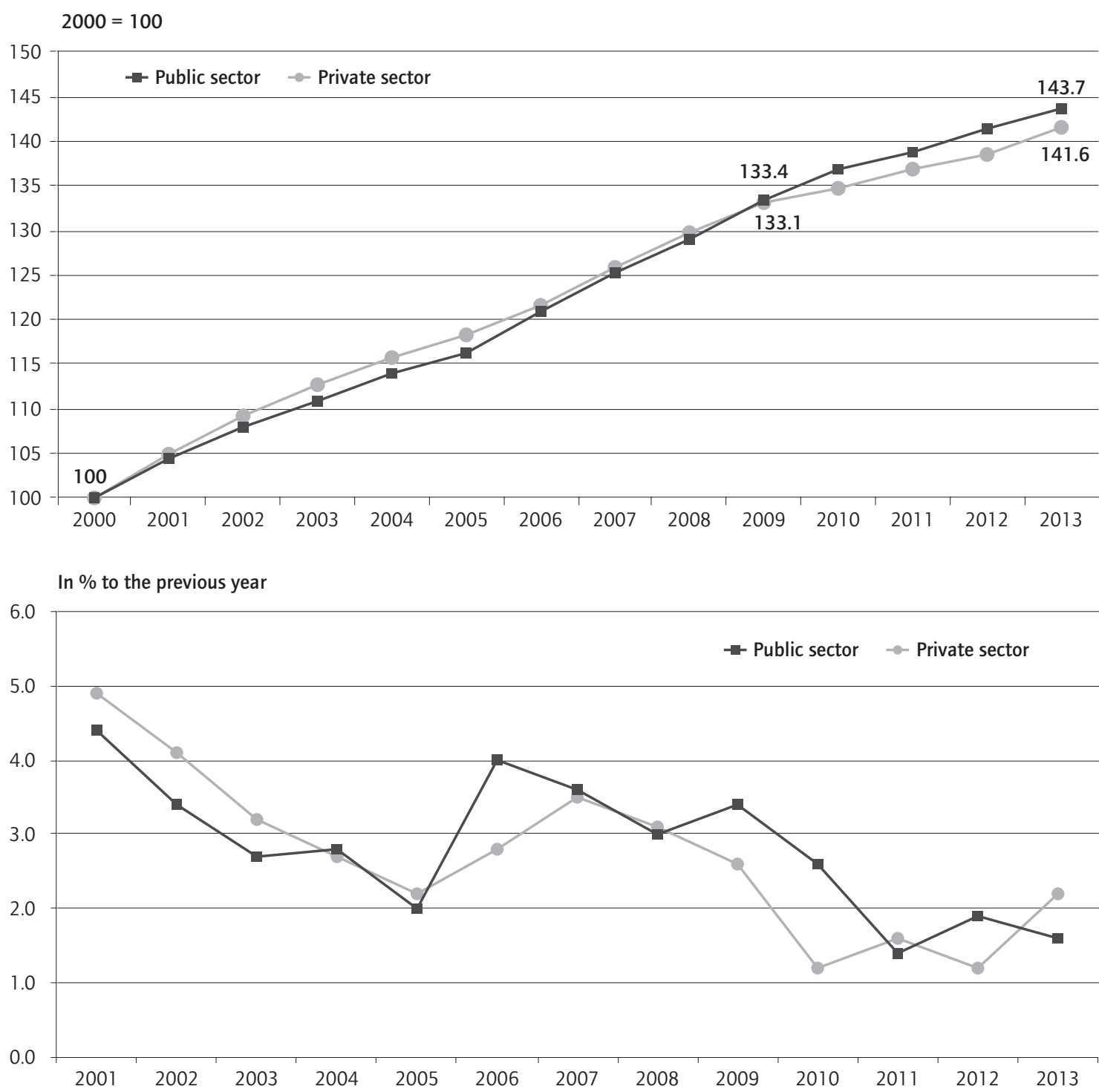

Private Sector: NACE Code B-N (Business economy)

Public Sector: NACE Code O-S (Public administration and defence; compulsory social security; education; human health and social work activities; arts, entertainment and recreation)

Source: Eurostat 


\section{Poland}

Wage developments in public and private sector 2001-2013

Over the whole period 2001-2013, there was an almost parallel development of private and public sector wages. Only after 2009, public sector wages grew slightly stronger than in the private sector.

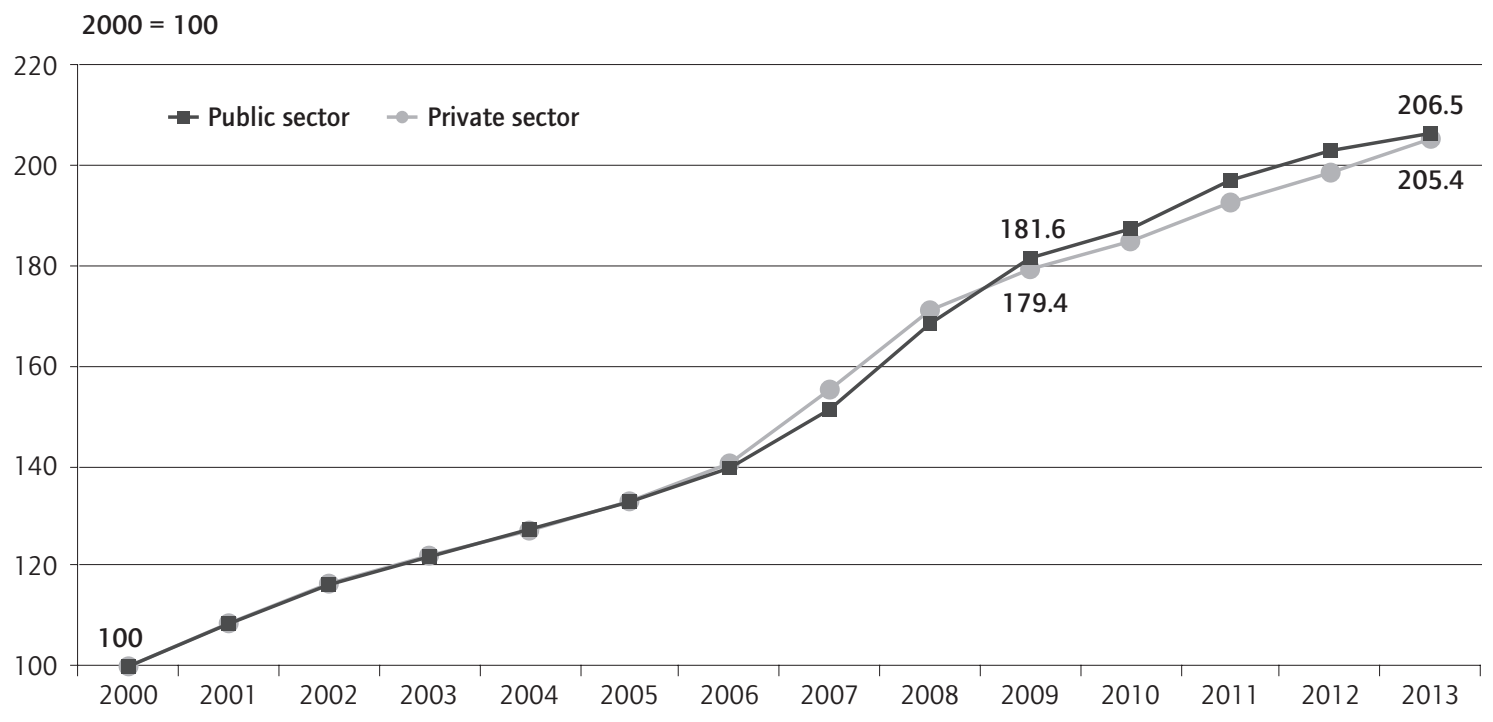

In $\%$ to the previous year

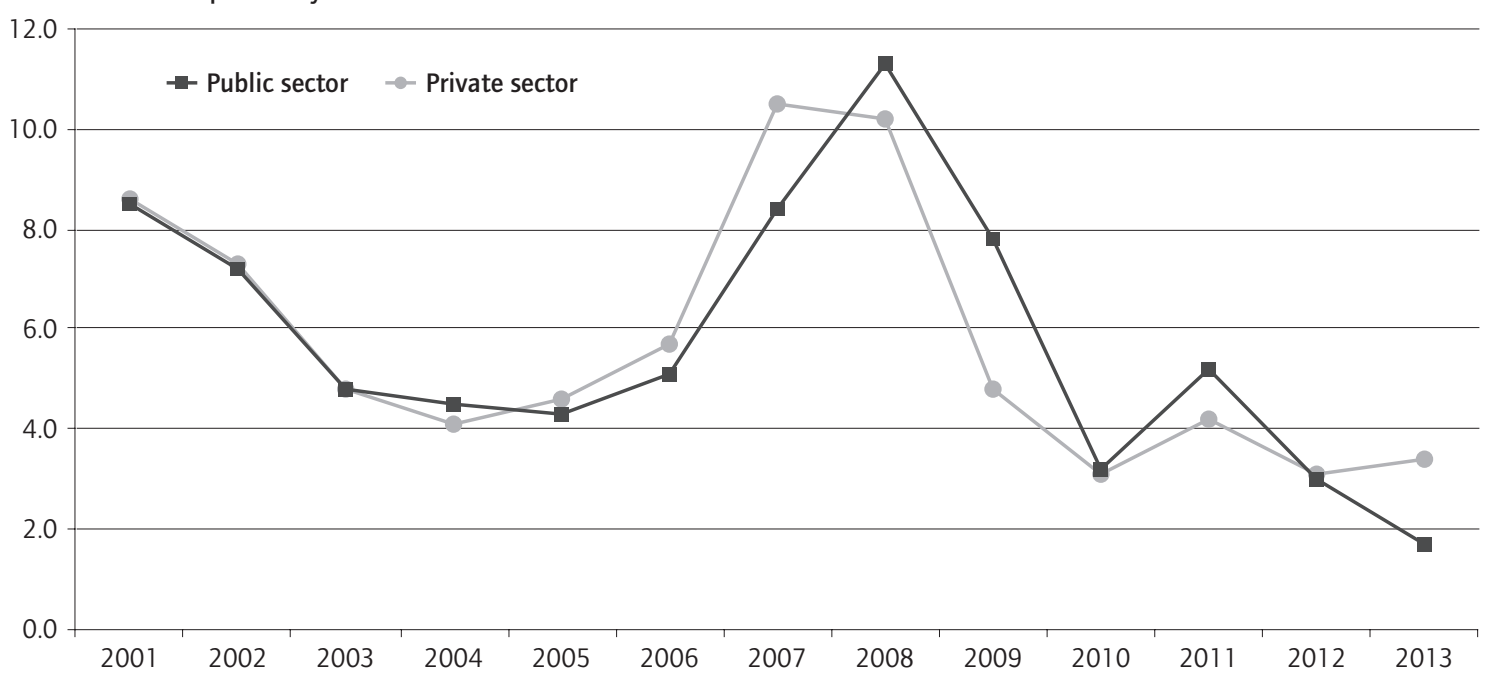

Private Sector: NACE Code B-N (Business economy)

Public Sector: NACE Code O-S (Public administration and defence; compulsory social security; education; human health and social work activities; arts, entertainment and recreation)

Source: Eurostat 


\section{Portugal}

\section{Wage developments in public and private sector 2001-2013}

In 2001 and 2002, public sector wage growth exceeded that of the private sector. Since then, the picture reversed as private sector wages often increased much more than wages in the public sector. Public sector wages also showed a strong decrease in the years 2010-2012 and only started to increase again in 2013. In the private sector, wages also decreased in the years 2012 and 2013.
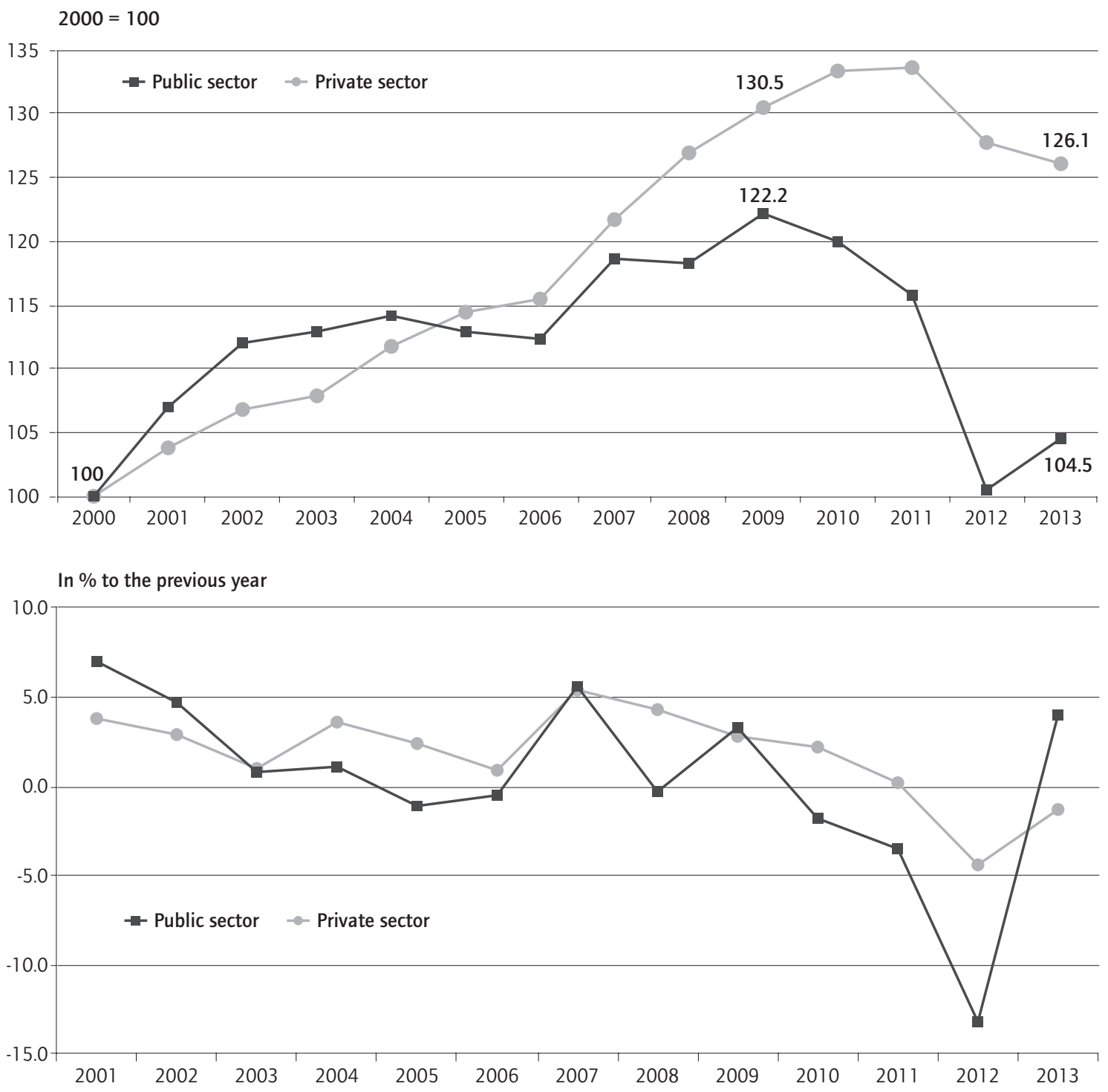

Private Sector: NACE Code B-N (Business economy)

Public Sector: NACE Code O-S (Public administration and defence; compulsory social security; education; human health and social work activities; arts, entertainment and recreation)

Source: Eurostat 


\section{Romania}

\section{Wage developments in public and private sector 2001-2013}

Between 2001 and 2005, there was an almost parallel development of private and public sector wages. From 2006 to 2009, public sector wages grew much faster than in the private sector. In 2010, there was a sharp drop of wages in the public sector while private sector wages continued to increase. In 2012 and 2013, public sector wages caught up again with developments in the private sector.

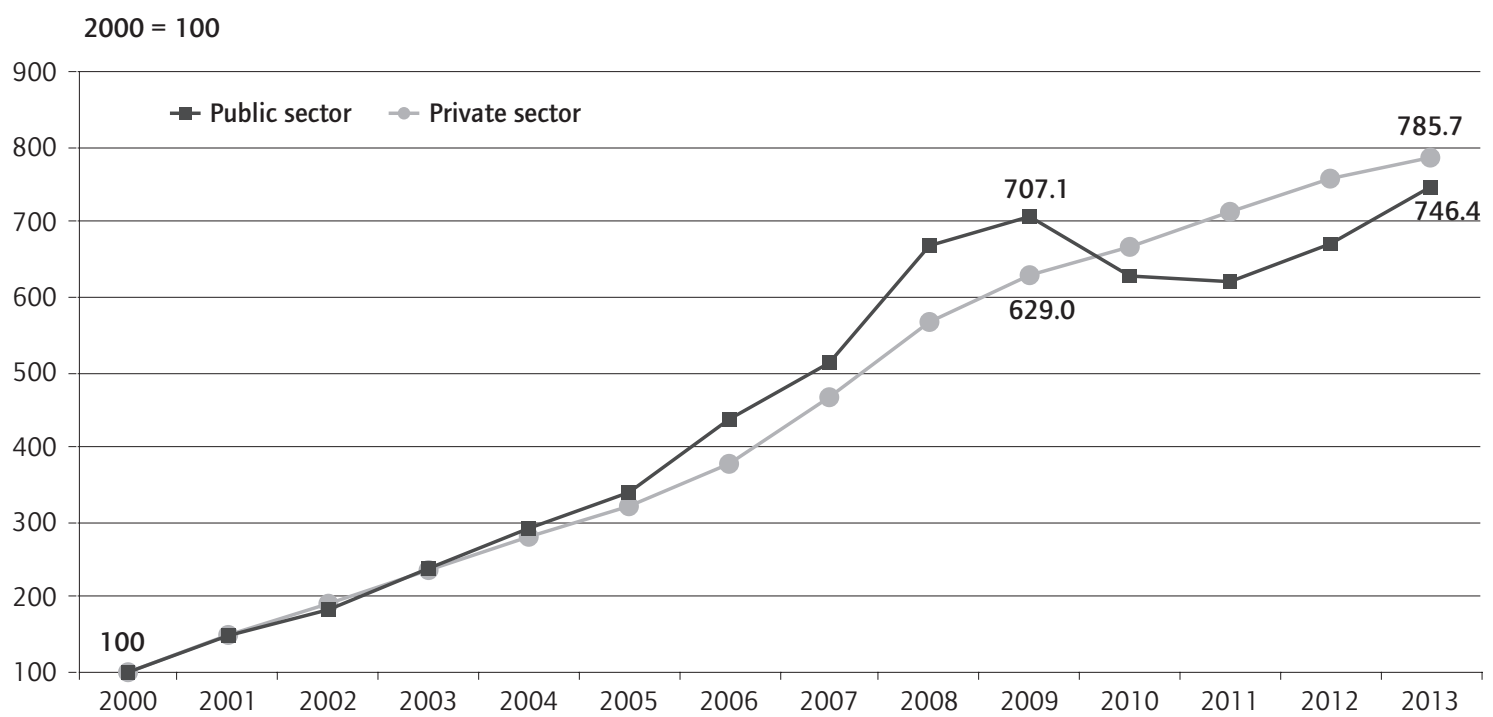

In $\%$ to the previous year

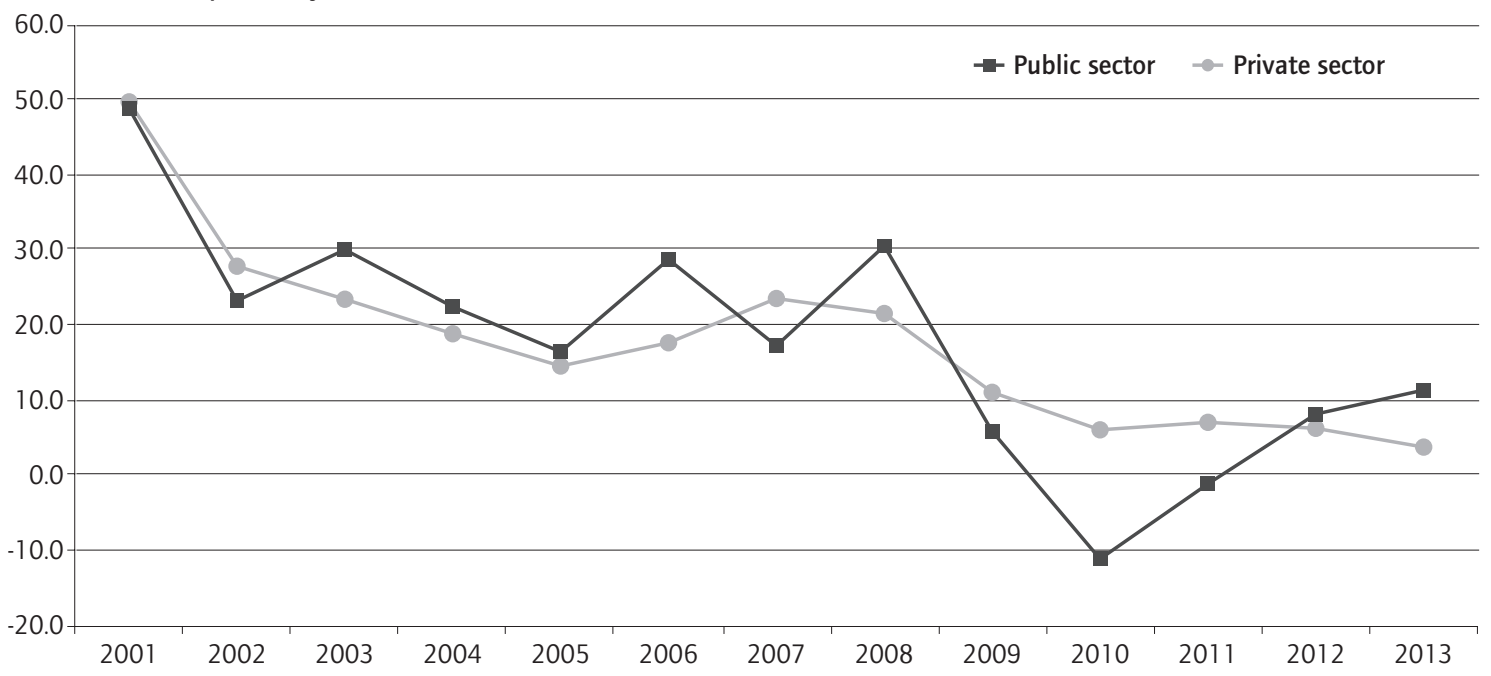

Private Sector: NACE Code B-N (Business economy)

Public Sector: NACE Code O-S (Public administration and defence; compulsory social security; education; human health and social work activities; arts, entertainment and recreation)

Source: Eurostat 


\section{Slovakia}

\section{Wage developments in public and private sector 2001-2013}

Over the whole period 2001-2013, public sector wages grew significantly faster in the public than in the private sector. The only main exception was the year 2011 when public sector wages were frozen and private sector wages increased quite substantially.

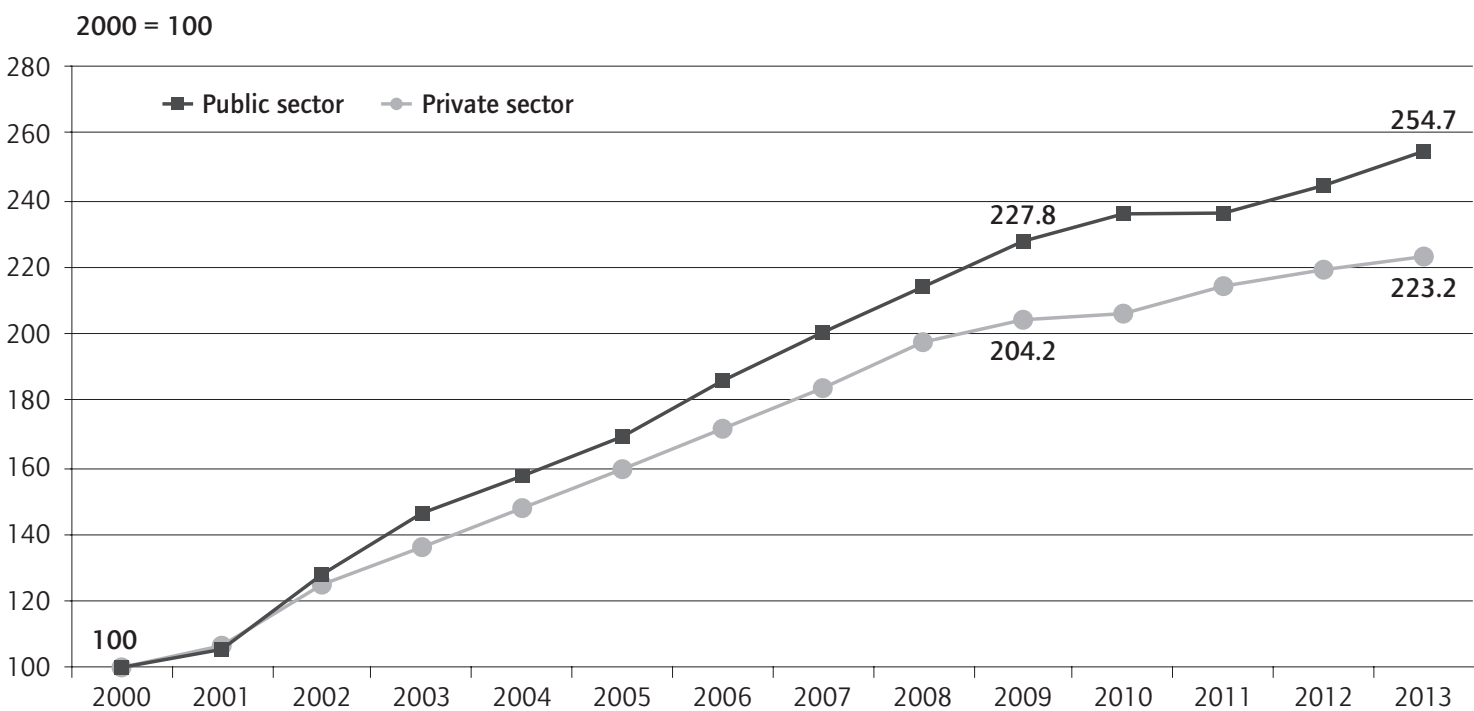

In $\%$ to the previous year

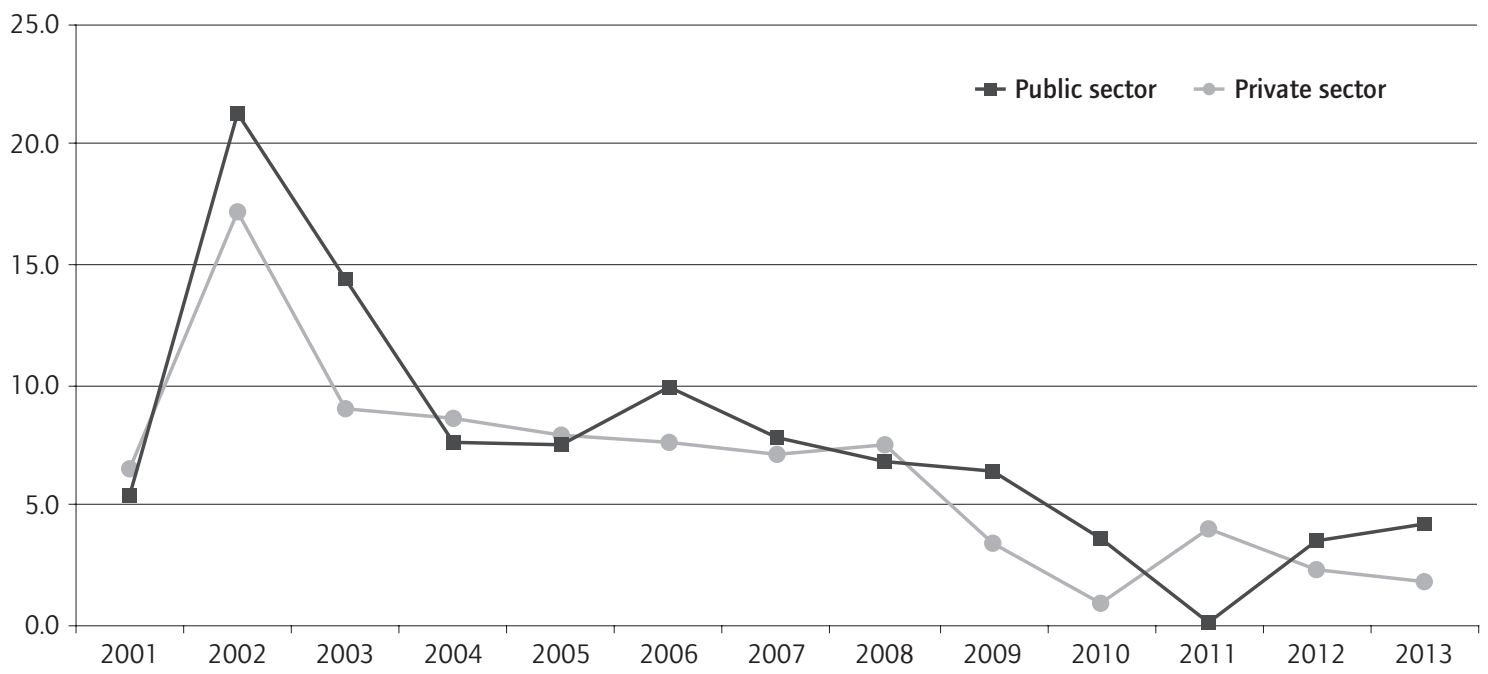

Private Sector: NACE Code B-N (Business economy)

Public Sector: NACE Code O-S (Public administration and defence; compulsory social security; education; human health and social work activities; arts, entertainment and recreation)

Source: Eurostat 


\section{Slovenia}

Wage developments in public and private sector 2001-2013

Apart from the years 2001 and 2009, private sector wages, as a rule, grew much faster than wages in the public sector. In 2010, 2012 and 2013, public sector wages even decreased significantly. Private sector wages have also decreased in 2013.

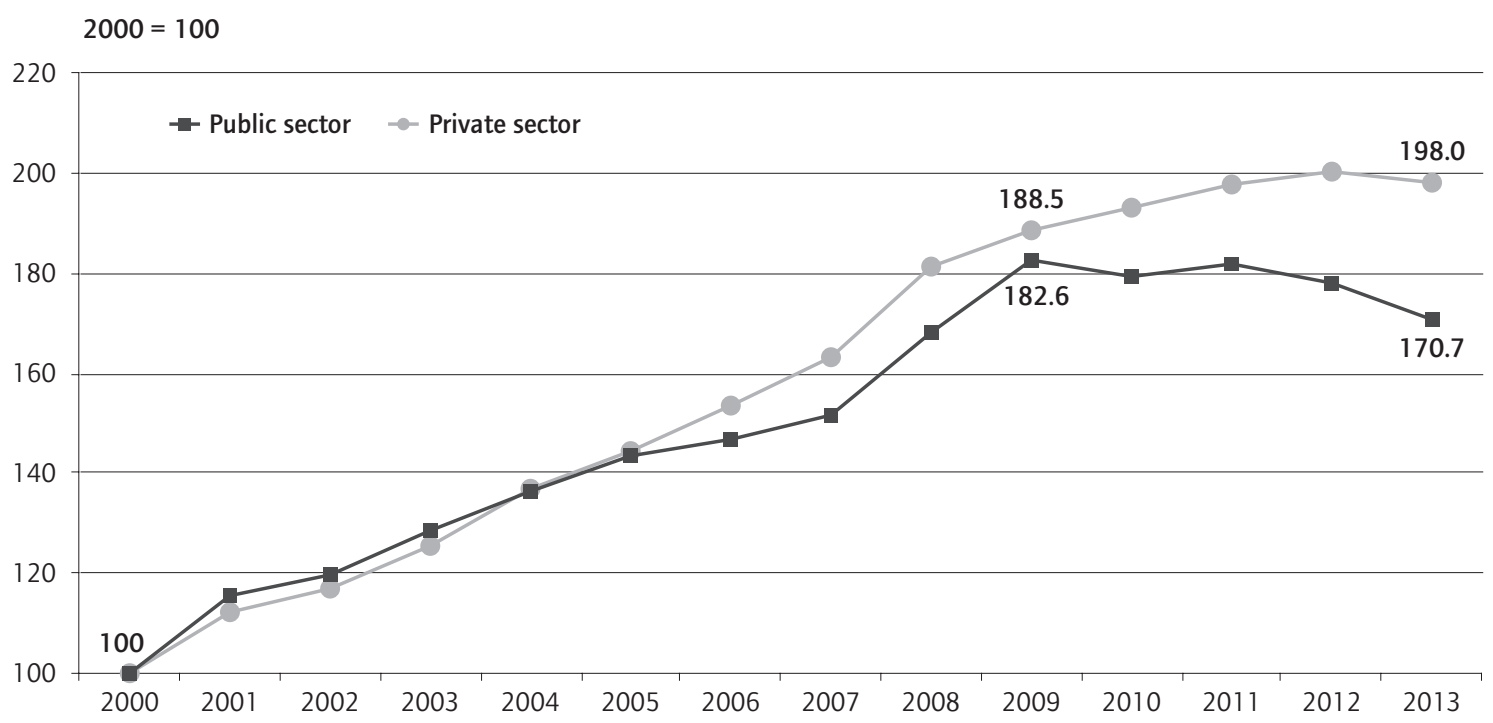

In $\%$ to the previous year

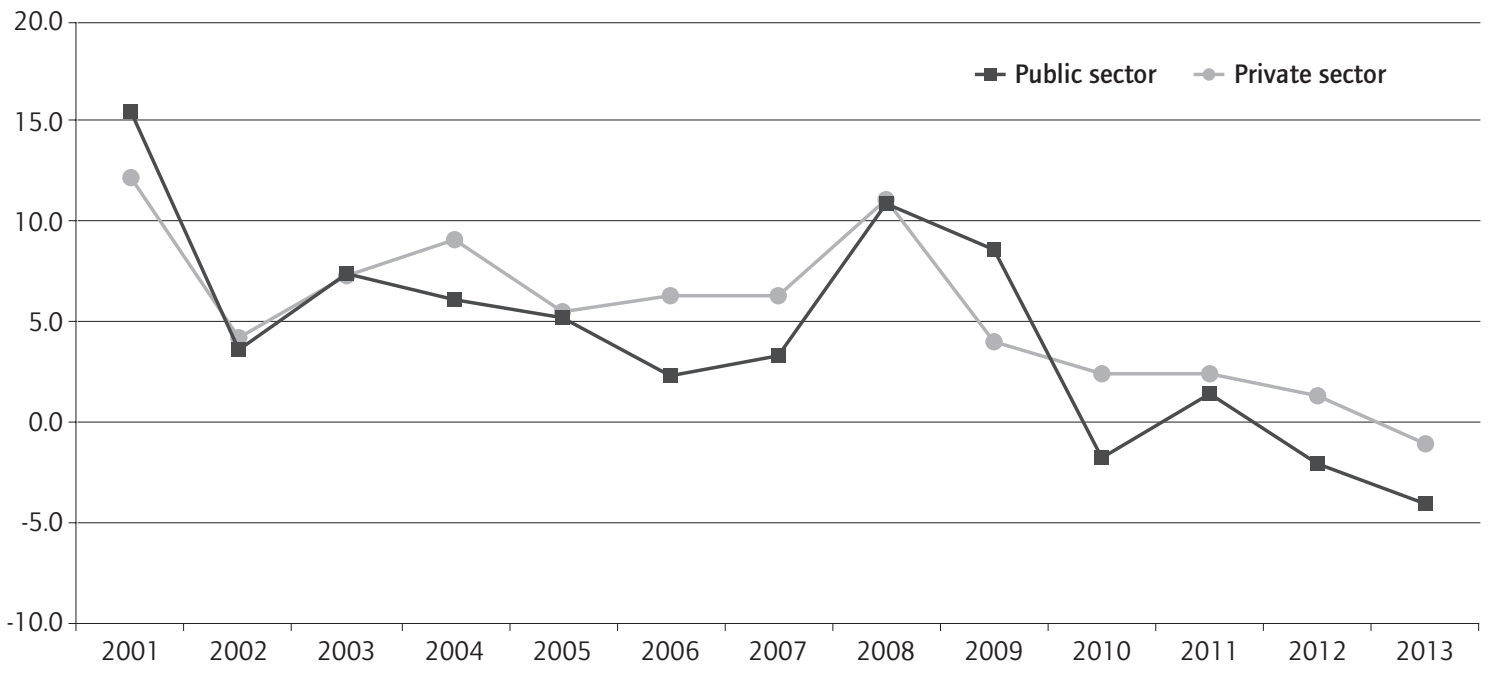

Private Sector: NACE Code B-N (Business economy)

Public Sector: NACE Code O-S (Public administration and defence; compulsory social security; education; human health and social work activities; arts, entertainment and recreation)

Source: Eurostat 


\section{United Kingdom}

\section{Wage developments in public and private sector 2001-2013}

Between 2001 and 2008, there was an almost parallel development of private and public sector wages. Between 2009 and 2011, wages in the public sector grew somewhat faster than in the private sector. After that, private sector wages grew somewhat faster. In 2012, public sector wages showed a significant decrease while private sector wages continued to grow.

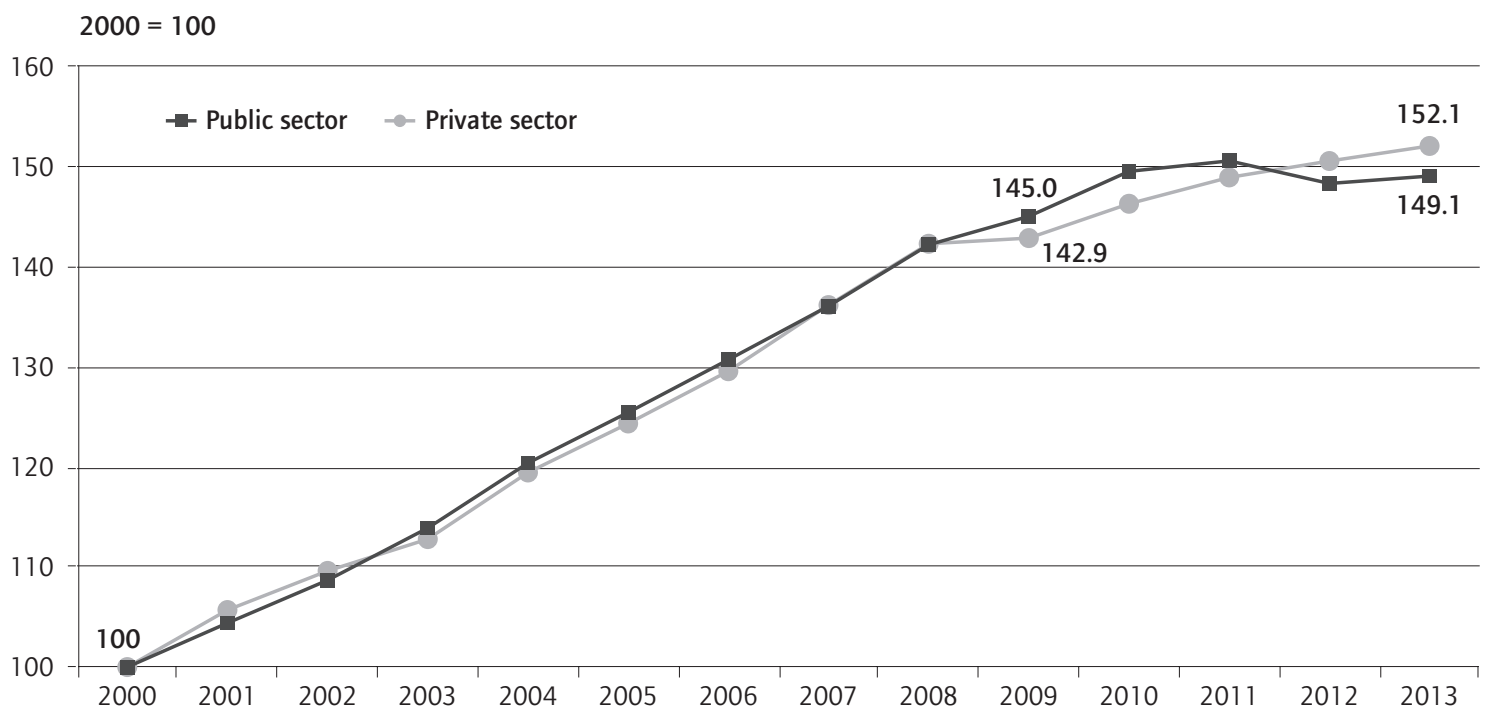

In $\%$ to the previous year

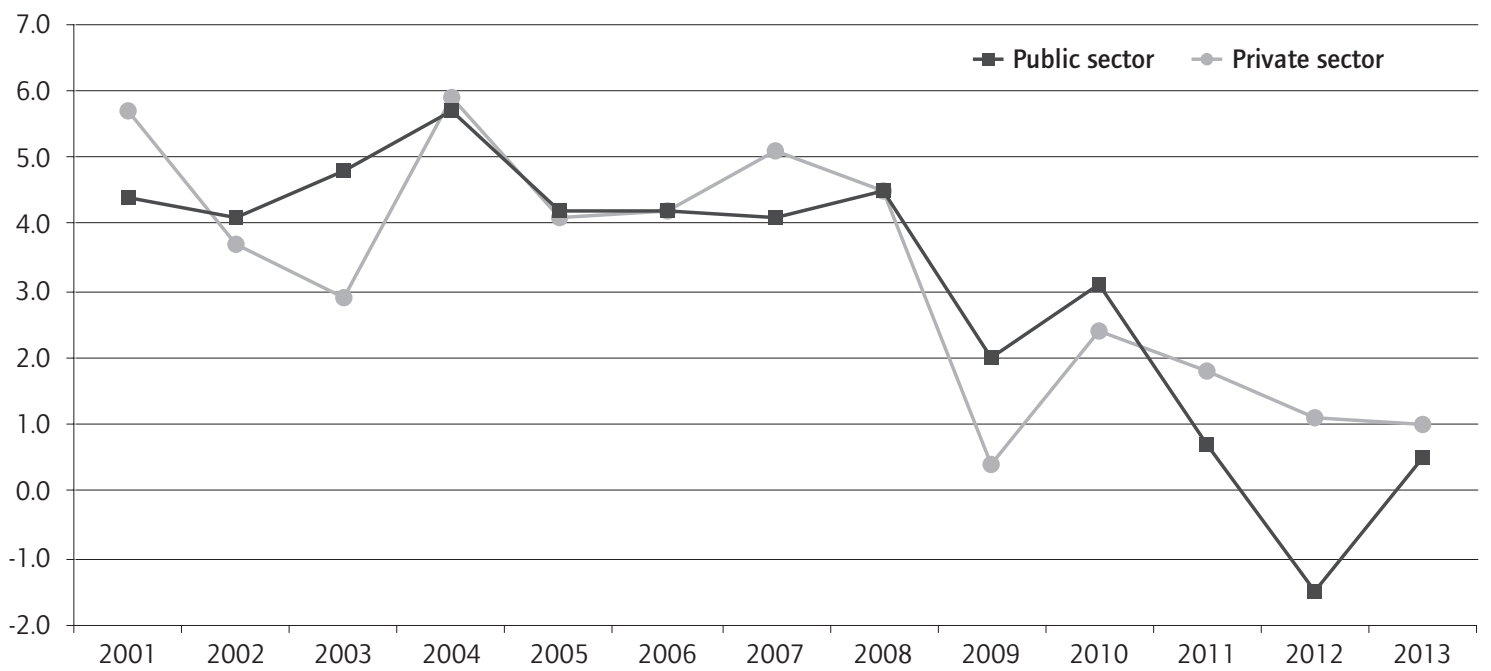

Private Sector: NACE Code B-N (Business economy)

Public Sector: NACE Code O-S (Public administration and defence; compulsory social security; education; human health and social work activities; arts, entertainment and recreation)

Source: Eurostat 


\section{ETUI Working Papers}

The Transatlantic Trade and Investment Partnership (TIP):

a controversial agreement and dangerous for workers

Working Paper 2015.07

Claude Serfati

Free movement of labour in Europe: a solution for better labour allocation?

Working Paper 2015.06

Béla Galgóczi and Janine Leschke

Beyond the CEE 'black box': crisis and industrial relations in the new EU member states Working Paper 2015.05

Magdalena Bernaciak

"Better Regulation": a bureaucratic simplification with a political agenda

Working Paper 2015.04 / EN, FR

Éric Van den Abeele

Spain's labour market reforms: the road to employment - or to unemployment?

Working Paper 2015.03

Laszlo Horwitz and Martin Myant

The European sectoral social dialogue: an uneven record of achievement?

Working Paper 2015.02 / EN, FR

Christophe Degryse

The TIIP's impact: bringing in the missing issue

Working Paper 2015.01

Martin Myant M. and Ronan O'Brien

Trade union membership retention and workplace representation in Europe.

Questions on the renewal of trade union organisation

Working Paper 2014.10

Jeremy Waddington

About the baby and the bathwater: assessing the European Platform against Poverty Working Paper 2014.09

Sebastiano Sabatiano and Bart Vanhercke

Integrating social and environmental dimensions in public procurement: one small step for the internal market, one giant leap for the EU?

Working Paper 2014.08 / EN, FR

Éric Van den Abeele 
Why have some countries become more unemployed than others? An investigation of changes in unemployment in EU member states since 2008

Working Paper 2014.07

Martin Myant and Agnieszka Piasna

These publications can be downloaded free of charge from our website.

Please visit: www.etui.org/publications 